Florida A\&M University College of Law

Scholarly Commons @ FAMU Law

Return of the Great Writ: Judicial Review, Due Process, and the Detention of Alleged Terrorists as Enemy Combatants

Benjamin Priester

Follow this and additional works at: https://commons.law.famu.edu/faculty-research

Part of the Criminal Law Commons, Human Rights Law Commons, Military, War, and Peace Commons, and the National Security Law Commons 


\title{
RETURN OF THE GREAT WRIT: JUDICIAL REVIEW, DUE PROCESS, AND THE DETENTION OF ALLEGED TERRORISTS AS ENEMY COMBATANTS
}

\author{
Benjamin J. Priester ${ }^{*}$ \\ TABLE OF CONTENTS
}

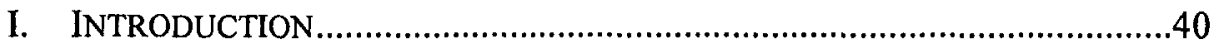

II. DOCTRINAL AND FACTUAL BACKGROUND ......................................42

A. Detention of Individuals Under Civilian Law ..................................43

1. Detention in the Criminal Justice Process ...................................43

2. Non-Punitive Civil Detention...................................................46

3. Limits on Interrogation in Civilian Custody...............................47

B. Detention of Enemy Combatants Under Military Law .......................49

C. The "War" Against Terrorism ....................................................52

1. Constitutional and Statutory War Powers Relating to Detention 53

2. Responses to the September 11 th Attacks ...................................57

3. Litigation Concerning the Detention of Enemy Combatants ......61

D. The Open Questions About Judicial Review of Enemy Combatant

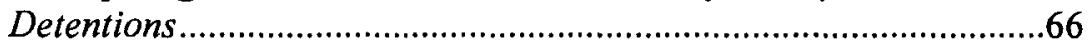

III. WRIT OF HABEAS CORPUS: PROCEDURAL THRESHOLDS.........................68

A. Standing and Personal Jurisdiction: Petitioner and Respondent.....70

B. Subject-Matter Jurisdiction ................................................................76

IV. WRIT OF HABEAS CORPUS: JUDICIAL REVIEW OF THE CONSTITUTIONALITY OF DETENTION ....................................................8

A. The Laws of War and of Alleged Terrorists ....................................82

B. Due Process and United States Citizens.........................................89

1. Deprivations of Liberty in Enemy Combatant Detentions..........92

2. Burden of Proof.........................................................................99

a. Seized in the United States...................................................94

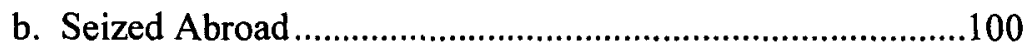

c. Concessions and "Undisputed" Facts.................................101

3. Access to Counsel and Related Procedural Protections ............103

* Assistant Professor, Florida State University College of Law. I thank Steve Gey, Greg Mitchell, Jim Rossi, Mark Seidenfeld, and the participants in FSU's faculty enrichment workshop for comments and suggestions. 


\section{INTRODUCTION}

The federal government's reaction to the terrorist attacks of September 11,2001 , included a wide range of statutes, policies, and strategies for aggressively pursuing, capturing, detaining, and punishing not only the individuals directly responsible for the attacks, but also those who seek to carry out future attacks. The objective was no less ambitious than the elimination of the entire terrorist organization known as Al Qaeda, from its leaders like Osama bin Laden to its agents in the field. ${ }^{1}$ To accomplish this aim the government invoked the full range of its powers in foreign and domestic affairs: military force abroad, foreign intelligence gathering, cooperation with international allies, immigration laws, military tribunals, civilian arrests and prosecutions, grand jury investigations, and more. ${ }^{2}$ This massive effort provoked praise and outrage about nearly every facet of its scope and particulars from a wide variety of perspectives. ${ }^{3}$

This Article examines a single piece of the vast antiterrorism mosaic: the proper role of judicial review, through the procedure of a petition for the writ of habeas corpus, of the detention of a United States citizen as an "enemy combatant" under the laws of war based on the government's allegation that the individual is a terrorist. These prisoners are held outside the rubric of the

1. See, e.g., Address Before a Joint Session of the Congress on the State of the Union, 38 WeEkLY COMP. Pres. Doc. 133, 134-36 (Jan. 29, 2002) (speech by President George W. Bush describing objectives of antiterrorism efforts).

2. See infra notes 78-79 and accompanying text (discussing USA Patriot Act); infra note 83 (discussing military tribunals). See generally United States v. Moussaoui, 365 F.3d 292 (4th Cir. 2004) (discussing criminal prosecution of alleged terrorist), cert. denied, $125 \mathrm{~S}$. Ct. 1670 (2005); United States v. Awadallah, 349 F.3d 42 (2d Cir. 2003) (discussing grand jury investigation of terrorism), cert. denied, $125 \mathrm{~S}$. Ct. 861 (2005); DAvID COLE, ENEMY ALIENS (2002) (discussing immigration laws); David Cole, Enemy Aliens, 54 STAN. L. REV. 953 (2002) (same).

3. See, e.g., Bruce Ackerman, The Emergency Constitution, 113 YALE L.J. 1029, 1307 41 (2004); Raquel Aldana-Pindell, The 9/11 "National Security" Cases: Three Principles Guiding Judges' Decision-Making, 81 OR. L. REv. 985, 1048-49 (2002); David Cole, Judging the Next Emergency: Judicial Review and Individual Rights in Times of Crisis, $101 \mathrm{MiCH}$. L. REv. 2565, 2594-95 (2003); David Cole, The New McCarthyism: Repeating History in the War on Terrorism, 38 HARV. C.R.-C.L. L. REV. 1, 3, 28-30 (2003); Nathan Watanabe, Internment, Civil Liberties, and a Nation in Crisis, 13 S. CAL. INTERDISC. L.J. 167, 192-93 (2003). See generally DAVID COLE \& JAMES X. DEMPSEY, TERRORISM AND THE CONSTITUTION: SACRIFICING Civil LiberTies IN THE NAME OF NATIONAL SECURITY (2002). 
ordinary criminal justice process in the custody of the United States Armed Forces. As such, they are denied the constitutional rights usually taken for granted when the government deprives a person of liberty. Therefore, the President's classification of a citizen as an enemy combatant, rather than an ordinary criminal, has consequences of tremendous significance, and determining the role of the courts in reviewing those classifications is of paramount importance.

Despite the fundamental nature of the issue, however, the role of judicial review in this context is surprisingly unclear, and the courts have yet to reach-much less resolve-many of the most basic questions. Even the June 2004 trio of United States Supreme Court opinions in Hamdi v. Rumsfeld, ${ }^{4}$ Rumsfeld v. Padilla, ${ }^{5}$ and Rasul v. Bush ${ }^{6}$ left most of these matters unresolved. This Article confronts those questions and proposes answers to them.

The Article begins in Part II by reviewing the framework of constitutional and statutory law that governs the detention of persons. It first considers detention under provisions of civilian law, including arrests of alleged criminals and incapacitation of dangerous persons in non-punitive proceedings. It then describes the power to detain enemy combatants under the laws of war and to try them before military tribunals, as well as discusses the manner in which that power has actually been exercised and the precedent and contemporary rulings the courts have made concerning it. Finally, it explains the questions left open by these doctrines and practice that the Article will answer.

In Part III the Article briefly examines the jurisdictional thresholds for habeas petitions challenging an enemy combatant detention. First are the requirements that the petitioner have standing to assert the prisoner's interests in contesting the detention and that the claim be brought against the appropriate respondent in the appropriate forum. Second is the requirement that the petitioner's claims be within the court's subject-matter jurisdiction; even the right of citizens to file habeas petitions is not definitively settled in all instances.

Part IV of the Article analyzes the fundamental questions - so far left unanswered by the courts-concerning judicial review of the detention of alleged terrorists as enemy combatants. To adjudicate the constitutionality of
4. 124 S. Ct. 2633 (2004).
5. 124 S. Ct. $2711(2004)$.
6. 124 S. Ct. $2686(2004)$. 
such prisoners' detentions requires determination of the requirements of the Due Process Clause, including the government's burden of proof, the appropriate methods for establishing that proof, the prisoners' access to counsel, and the concession or stipulation of undisputed facts. The due process analysis also depends, in part, upon an evaluation of how the doctrine of enemy combatant detentions should be adapted to account for the elusive nature of the battlefields on which the conflict is waged, particularly with respect to citizens seized within the United States before carrying out a terrorist attack.

The Article concludes that due process principles mandate that the government surpass substantial procedural requirements before imposing the significant deprivations of liberty inflicted by an enemy combatant detention. Although citizens may be detained in military custody as enemy combatants, the government possesses this authority only if it can prove that the individual is in fact a belligerent engaged in armed conflict against the United States under the laws of war. This requires proof not only of active present membership in a terrorist organization, but also specific intent to carry out imminent acts of terrorism. Furthermore, the Due Process Clause requires that the government prove that the citizen is an enemy combatant by clear and convincing evidence to the court hearing the habeas petition. Due process also requires that the petitioner be given a number of important procedural protections in the hearing, including the right to counsel and the right to challenge the government's evidence. Only if the government can carry its burden under these rigorous procedures may it detain a citizen as an enemy combatant.

\section{DOCTRINAL AND FACTUAL BACKGROUND}

The issue of the scope of judicial review of the detention of alleged terrorists as enemy combatants implicates a number of significant, longstanding doctrines of both civilian and military law. On the civilian side, constitutional doctrines of criminal procedure and non-punitive civil detention govern the arrest, detention, and incarceration of individuals. On the military side, the rules governing the power to detain and the conditions of detention applicable to persons as enemy combatants have substantial and crucial differences from the otherwise applicable civilian procedures. Thus, the power of the federal courts to review the President's designation of an individual as an enemy combatant has far-reaching effects.

One small component of the government's reaction to the September 11 th terrorist attacks was the President's decision to detain several hundred 
persons as alleged enemy combatants and to issue an Executive Order providing for the possibility of trials by military tribunal for them. Whether the President had constitutional or statutory power to take these actions has been the subject of considerable debate and some litigation. Because of the factual circumstances in which these actions took place and in which precedents arose, however, several fundamental questions about the scope of the federal government's power to detain alleged terrorists as enemy combatants remained unanswered.

\section{A. Detention of Individuals Under Civilian Law}

The Constitution provides a number of bases upon which the government may detain individuals. Some grounds, like incarceration for a criminal offense or involuntary civil commitment of dangerous mentally ill persons, have substantial procedural hurdles. Others, like the arrests of criminal suspects or the filing of criminal charges, may be carried out under much less rigorous procedures. Taken together, these doctrines form the civilian law framework against which the military law detention of alleged enemy combatants must be evaluated.

\section{Detention in the Criminal Justice Process}

The federal government may detain individuals in connection with the investigation or the prosecution of criminal offenses through a variety of procedures. The number and the degree of the procedural requirements that the government must satisfy to constitutionally invoke such detentions are directly proportional to the nature and the length of the deprivation of liberty involved.

On one end of the continuum is a deprivation of liberty for a term of imprisonment pursuant to a conviction for a criminal offense. To obtain such a conviction, the government must provide the accused with the familiar list of constitutional protections, including the right to trial by jury, the right to counsel, the right to confront witnesses, and the government's burden of proving guilt beyond a reasonable doubt. ${ }^{\text {T }}$ These procedural requirements

7. See U.S. CONST. amends. V-VI; In re Winship, 397 U.S. 358, 364 (1970). See generally 3 WAYNE LAFAVE ET AL., CRIMINAL PROCEDURE ch. 24 (3d ed. 2000 \& Supp. 2003). 
serve as a bulwark against tyranny by precluding the government from imprisoning persons except upon the most persuasive proof. ${ }^{8}$

At the other end of the continuum are brief, temporary detentions in exercise of the government's investigations or prosecutions of offenses. For example, when criminal investigations are carried out by a grand jury, subpoenas may be issued to compel individuals to appear and to testify. Because of the limited imposition on liberty caused by such subpoenas and the historical and constitutional role of the grand jury, they may be issued on the very low threshold of "relevance" to the grand jury's investigation." Similarly, upon "reasonable suspicion," a law enforcement officer may briefly stop a person for investigative purposes without the encounter constituting an arrest. ${ }^{10}$

A person suspected of having committed a criminal offense may be arrested and taken into custody. ${ }^{11}$ The Fourth Amendment requires that this seizure be "reasonable" and that the government be able to demonstrate "probable cause" that the person is responsible for the alleged offense. ${ }^{12}$ The sufficiency of the government's evidence of probable cause is subject to judicial review-either beforehand through the issuance of an arrest warrant or afterward at a hearing within forty-eight hours - but that review may be ex parte and non-adversarial. ${ }^{13}$ Similarly, federal felony charges may be filed only pursuant to an indictment approved by a grand jury upon a finding of probable cause. ${ }^{14}$

8. See United States v. Gaudin, 515 U.S. 506, 510-11 (1995) (quoting 4 WilliaM BLACKSTONE, COMMENTARIES ON THE LAWS OF ENGLAND 343 (1769), and 2 JOSEPH STORY, COMMENTARIES ON THE CONSTITUTION OF THE UNITED STATES 540-41 \& n.2 (4th ed. 1873)) (discussing importance of right to jury trial); Winship, 397 U.S. at 361-64 (discussing importance of proof beyond a reasonable doubt); Duncan v. Louisiana, 391 U.S. 145, 151-54 (1968) (discussing importance of right to trial by jury).

9. See United States v. R. Enters., Inc., 498 U.S. 292, 297 (1991); United States v. Dionisio, 410 U.S. 1, 15 (1969); 2 LAFAVE ET AL., supra note 7, § 8.8.

10. See Illinois v. Wardlow, 528 U.S. 119, 123-24 (2000); Terry v. Ohio, 392 U.S. 1, 30-31 (1968); 1 LAFAVE ET AL., supra note 7, § 3.8.

11. See Atwater v. City of Lago Vista, 532 U.S. 318, 326 (2001); 1 LAFAvE ET AL., supra note 7, §3.5(a).

12. U.S. CONST. amend. IV; see also Atwater, 532 U.S. at 326; 1 LAFAVE ET AL., supra note $7, \S 3.5(\mathrm{a})$.

13. See County of Riverside v. McLaughlin, 500 U.S. 44, 63 (1991); 1 LAFAVE ET AL., supra note 7, § 3.5(a).

14. See R. Enters., Inc., 498 U.S. at 297; United States v. Mechanik, 475 U.S. 66, 67 (1986); 2 LAFAVE ET AL., supra note $7, \S 15.2(\mathrm{f})$. The existence of a pending indictment is 
Additionally, in certain limited circumstances, a witness whose testimony is material to a federal criminal case may be arrested to ensure that the testimony can be obtained. ${ }^{15}$ The Second Circuit has concluded that such "material witness warrants" may be used to detain witnesses who will be called to testify before a grand jury. ${ }^{16}$ Like the arrest of a criminal suspect, the arrest of a material witness is subject to judicial oversight. ${ }^{17}$

Under the federal bail statute, persons who have been arrested are entitled to be released on whatever combination of financial or non-financial conditions the judge presiding over the bail hearing determines will ensure the person's appearance and the public safety pending further proceedings. ${ }^{18}$ A criminal suspect charged with an offense, or a material witness arrested to ensure her testimony will be given, may be detained in government custody without release only if, after an adversarial hearing at which the person was represented by counsel and had the right to present evidence and witnesses and to contest the government's allegations, the judge finds by clear and convincing evidence that "no condition or combination of conditions will reasonably assure the appearance of the person and the safety of any other

itself a sufficient deprivation of liberty to constitute "custody" that may be challenged in a habeas petition. See Braden v. 30th Jud. Cir. Ct., 410 U.S. 484, 488-89 (1973).

15. See 18 U.S.C. $\$ 3144$ (2000). The statute states that "it may become impracticable to secure the presence of the person by subpoena" before permitting the witness to be arrested, and authorizes detention "for a reasonable period of time until the deposition of the witness can be taken" only if conditions of bail cannot ensure compliance with release pending the taking of a deposition. Id.

16. United States v. Awadallah, 349 F.3d 42, 60 (2d Cir. 2003), rev'g 202 F. Supp. 2d 82 (S.D.N.Y. 2002), and 202 F. Supp. 2d 55 (S.D.N.Y. 2002), and approving In re Material Witness Warrant, 213 F. Supp. 2d 287 (S.D.N.Y. 2002), cert. denied, 125 S. Ct 861 (2005). The appropriate scope for the use of material witness warrants in antiterrorism investigations is analyzed in a number of sources. See, e.g., Michael Greenberger, Indefinite Material Witness Detention Without Probable Cause: Thinking Outside the Fourth Amendment, in AT WAR WITH CIVIL RJGHTS AND CIVIL LiberTIES 83, $88-92$ (Baker \& Stack eds., 2005); Robert Boyle, The Material Witness Statute Post-September llth: Why It Should Not Include Grand Jury Witnesses, 48 N.Y.L. SCH. L. REV. 13, 18 (2004); Roberto Iraola, Terrorism, Grand Juries, and the Federal Material Witness Statute, 34 ST. MARY's L.J. 401, 402-03 (2003); Laurie L. Levenson, Essay: Detention. Material Witnesses \& the War on Terrorism, 35 LoY. L.A. L. REv. 1217, 1225 (2002); Stacey M. Studnicki \& John P. Apol, Witness Detention and Intimidation: The History and Future of Material Witness Law, 76 ST. JOHN's L. REv. 483, 511-15 (2002); Timothy John Casey, Comment, United States v. Awadallah: Uncle Sam Wants You to Spend Eighty-Three Days Behind Bars? An Analysis of the Case and Its Implications for Fourth Amendment Jurisprudence, 78 ST. JOHN's L. REV. 185, 189 (2004).

17. See 18 U.S.C. $\$ 3144$ (requiring application of bail procedures in id. $\$ 3142$ ).

18. See id. §3142(a)-(c). 
person and the community." ${ }^{\prime 19}$ In United States v. Salerno, the Supreme Court upheld the constitutionality of these "preventive detention" provisions against challenges under the Due Process Clause and the Eighth Amendment's prohibition on excessive bail. ${ }^{20}$ At the hearing in that case, the government had met its burden with the presentation of extensive evidence, including recordings from wiretaps and the testimony of witnesses, that the defendants were leaders of the Genovese crime family in New York and would continue to pose a threat of violent crime in the community if not detained preventively. ${ }^{21}$

\section{Non-Punitive Civil Detention}

The Constitution also permits detention of persons on grounds independent of the criminal justice process. Although the fact of government custody resembles incarceration pursuant to a criminal conviction, the Supreme Court has upheld the constitutionality of such detentions on the basis that they are "non-punitive" and therefore civil in nature. ${ }^{22}$

The form of civil detention most closely related to the detention of enemy combatants is the involuntary, indefinite confinement of dangerous, mentally ill individuals in psychiatric facilities. In a series of recent cases, the Court held that so-called "sexual predators" could be compelled, after a full and fair adversarial hearing with counsel, to remain indefinitely confined to a secure hospital upon a showing by clear and convincing evidence that the individual is both dangerous and so severely mentally ill as to be unable

19. Id. $\$ 3142(\mathrm{e})-(\mathrm{g})$.

20. See 481 U.S. 739,755 (1987). The Court found no violation of substantive due process because the preventive detention at issue was regulatory, not punitive, in nature. See id. at 746-51; see also infra note 22 . The Court also held that the procedures required by the Act were sufficient to defeat a facial challenge grounded in procedural due process. See id. at 751-52. Finally, the Court concluded that prevention of danger to the community, and not only prevention of flight to avoid trial, was a compelling interest justifying the preventive detention provisions of the Act. See id. at 752-55.

21. See $i d$. at $743-44,755$. The defendants asserted that the Act was unconstitutional on its face; the Court decided the case on that basis, while noting that as-applied challenges might be raised in future cases. See id. at 745-46 \& n.3, 747 n.4, 752, 755.

22. See, e.g., Kansas v. Hendricks, 521 U.S. 346, 361-69 (1997); United States v. Salerno, 481 U.S. 739, 746-51 (1987); Kennedy v. Mendoza-Martinez, 372 U.S. 144, 168-69 (1963). Among other factors, the detention is punitive if it is imposed to serve purposes of retribution or general deterrence. See Kansas v. Crane, 534 U.S. 407, 412 (2002) (citing Hendricks, 521 U.S. at 372-73 (Kennedy, J., concurring)). 
to control that dangerous behavior. ${ }^{23}$ This doctrine makes equally clear, however, that the defendant must be released when he is either no longer mentally ill or no longer dangerous and is entitled to periodic review of those factors. ${ }^{24}$

Thus, like the "preventive detention" of accused criminals approved in Salerno, the confinement of dangerous, mentally ill persons is predicated on a substantial showing by the government that detention is the only viable method of avoiding a harm it has a compelling interest in preventing, such as flight from prosecution, obstruction of justice, or grave risk of danger to innocent persons.

\section{Limits on Interrogation in Civilian Custody}

Finally, additional constitutional protections apply across the range of these civilian detention powers: prohibitions against compulsory disclosure of incriminating information and coercive interrogation techniques.

The most famous and well-established protection is the Fifth Amendment privilege against compulsory self-incrimination. ${ }^{25}$ Even when the government properly invokes its power to detain a person, it cannot compel him to give statements that might incriminate him in connection with criminal activities. ${ }^{26}$ At trial or sentencing, or any other formal stage of a criminal proceeding, the accused has a right not to testify. ${ }^{27}$ Persons who have been arrested have a right to refuse to answer questions while in law enforcement custody, and statements made without a proper waiver of the Miranda warnings cannot be used against the person in a criminal prosecution. ${ }^{28}$ Similarly, persons subpoenaed to testify before a grand jury

23. See, e.g., Crane, 534 U.S. at 409-10; Seling v. Young, 531 U.S. 250, 255 (2001); Hendricks, 521 U.S. at 357-60; Foucha v. Louisiana, 504 U.S. 71, 80 (1992); Addington v. Texas, 441 U.S. 418, 426-27 (1979). In Crane, the Court explained that the person must have a "serious difficulty in controlling behavior" to be detained on grounds of dangerousness. 534 U.S. at 413.

24. See, e.g., Foucha, 504 U.S. at 82-83.

25. See U.S. CONST. amend. V ("nor shall [any person] be compelled in any criminal case to be a witness against himself').

26. See 2 LAFAVE ET AL., supra note 7, §§ 8.10-8.14.

27. See, e.g., Mitchell v. United States, 526 U.S. 314, 325 (1999); Griffin v. California, 380 U.S. 609, 613 (1965); 3 LAFAVE ET AL., supra note 7, § 24.5.

28. See, e.g., Dickerson v. United States, 530 U.S. 428, 431-32 (2000); Miranda v. Arizona, 384 U.S. 436, 444 (1966); 2 LAFAVE ET AL., supra note 7, $\$ \S 6.5-6.10$. Similarly, in McKune v. Lile, a divided Court held that a requirement that a sex offender disclose prior criminal acts in the course of a prison treatment program did not violate the Self-Incrimination 
may invoke the Self-Incrimination Clause privilege and can be compelled to testify only under a grant of immunity from prosecution. ${ }^{29}$ The Fifth Amendment privilege is a significant constraint on the government's techniques of investigation because the government often must forgo the possibility of prosecuting the person in order to compel him to provide information. ${ }^{30}$

Even in the absence of a violation of the Self-Incrimination Clause, the Due Process Clause places limits on the government's use of coercive interrogation techniques to extract information from individuals. ${ }^{31}$ In 2003, the Court unanimously reaffirmed in Chavez v. Martinez that due process prohibits interrogation techniques that "shock the conscience" or that are otherwise egregious. ${ }^{32}$ The Court repeatedly mentioned the use of torture as

Clause. 536 U.S. 24, 48 (2001). The Court was unanimous, however, that the prisoner could not be compelled to give incriminating statements during his confinement. See id. at 35-39; id. at 48-49 (O'Connor, J., concurring); id. at 55-57 (Stevens, J., dissenting).

29. See, e.g., United States v. Hubbell, 530 U.S. 27, $45-46$ (2000); Kastigar v. United States, 406 U.S. 441, 453 (1972). To the extent the information in question is not personally incriminating, however, the privilege does not apply, and the person can be compelled to testify. See, e.g., Ohio v. Reiner, 532 U.S. 17, 21 (2001); 2 LAFAVE ET AL., supra note 7, $\S 8.10$.

30. See, e.g., Hubbell, 530 U.S. at 45-46 (reversing conviction for violation of grant of immunity); United States v. North, 910 F.2d 843, 872 (D.C. Cir. 1990). For example, Department of Justice officials and commentators have noted that the extensive interrogation of José Padilia in violation of his Fifth Amendment rights will pose a substantial, if not insurmountable, obstacle to a civilian criminal prosecution if he is released from enemy combatant detention. See, e.g., Dan Christensen \& Vanessa Blum, U.S. May Indict Terror Suspect Held as Enemy: High Court Rulings Leave Government With Few Options in Padilla Case, Legal TIMES, July 5, 2004, at 1.

31. See Chavez v. Martinez, 538 U.S. 760, 773 (2003). In Chavez, a majority of the Court ruled that the Self-Incrimination Clause and the corollary Miranda warnings provide a remedy only against use of the individual's statements in a criminal case. Id. Thus, if the individual is not prosecuted, there can be no violation of the Self-Incrimination Clause that would be remedied or prevented by the exclusionary rule. Compare id. at 766-70 (asserting this position); id. at 777-78 (Souter, J., concurring); id. at 780 (Scalia, J., concurring), with id. at 790-93 (Kennedy, J., dissenting in part) (questioning this position); id. at 799-801 (Ginsburg, J., dissenting in part). See generally Thomas Y. Davies, Farther and Farther from the Original Fifth Amendment: The Recharacterization of the Right Against Self-Incrimination as a "Trial Right" in Chavez v. Martinez, 70 TENN. L. REv. 987 (2003) (providing an originalist critique of the Chavez majority's position).

32. 538 U.S. 760,774 (2003). Five Justices voted to remand the case for further factual development of the Due Process Clause claim arising from police interrogation of a criminal suspect during medical treatment for gunshot wounds, which the lower courts had not 
conduct that would violate the Due Process Clause. ${ }^{33}$ Although these due process limits remain relatively undefined in the case law, ${ }^{34}$ the Chavez Court's admonitions are noteworthy.

\section{B. Detention of Enemy Combatants Under Military Law}

Completely separate from the doctrines permitting detention of individuals under civilian law is a body of military law governing the detention of persons as enemy combatants under the laws of war. Such prisoners are outside the ordinary constitutional framework and instead may be held indefinitely in military custody and potentially may be interrogated or subject to the military justice system. Such dramatic differences from the civilian law have made enemy combatant detentions highly controversial.

The concept of enemy combatant detentions derives principally from the Geneva Convention, to which the United States is a signatory ${ }^{35}$ and which codified principles previously well-established in the customary international

adequately considered. See id. at 779-80 (opinion of Souter, J., for the Court); id. at 787-89 (Stevens, J., concurring in part); id. at 796 (Kennedy, J., dissenting in part). Four Justices concluded that as a matter of law, the police conduct in Chavez did not rise to the level of a Due Process Clause violation. See id. at $774-75$ (opinion of Thomas, J.).

33. See, e.g., id. at 773 (majority opinion) ("Our views on the proper scope of the Fifth Amendment's Self-Incrimination Clause do not mean that police torture or other abuse that results in a confession is constitutionally permissible so long as the statements are not used at trial; it simply means that the Fourteenth Amendment's Due Process Clause, rather than the Fifth Amendment's Self-Incrimination Clause, would govern the inquiry in those cases and provide relief in appropriate circumstances."); id. at 783-84 (Stevens, J., concurring in part) ("As a matter of fact, the interrogation of respondent was the functional equivalent of an attempt to obtain an involuntary confession from a prisoner by torturous methods. As a matter of law, that type of brutal police conduct constitutes an immediate deprivation of the prisoner's constitutionally protected interest in liberty."); id. at 789-90 (Kennedy, J., concurring in part) ("A constitutional right is traduced the moment torture or its close equivalents are brought to bear. Constitutional protection for a tortured suspect is not held in abeyance until some later criminal proceeding takes place."); id. at 796 (Kennedy, J., concurring in part) ("Turning to this essential, but less specific, guarantee, it seems to me a simple enough matter to say that use of torture or its equivalent in an attempt to induce a statement violates an individual's fundamental right to liberty of the person.").

34. See Seth F. Kreimer, Too Close to the Rack and the Screw: The Constitutional Constraints on Torture in the War on Terror, 6 U. PA. J. CONST. L. 278, 288-94 (2003) (discussing Chavez and other due process cases in relation to interrogation of terrorism suspects).

35. See Geneva Convention Relative to the Treatment of Prisoners of War, Aug. 12, 1949, 6 U.S.T. 3316, 75 U.N.T.S. 135 [hereinafter GCPW]. 
laws of war and predecessor treaties. ${ }^{36}$ Those principles were developed to account for situations involving wars or other "armed conflicts" between nations or within the territory of a single nation, ${ }^{37}$ such as World War II or the United States military action against the Taliban regime in Afghanistan. ${ }^{38}$ In the aftermath of September 11 th, the government also has sought to detain members of $\mathrm{Al}$ Qaeda, an independent, non-governmental terrorist organization, as enemy combatants. ${ }^{39}$

The Geneva Convention defines two categories of enemy combatants. Lawful enemy combatants are called "prisoners of war" and must be treated in accordance with the terms of the treaty, ${ }^{40}$ including the prohibition on interrogation beyond providing basic identifying information such as their name, rank, and serial number to the capturing power. ${ }^{41}$ Lawful enemy combatants may be detained, but they cannot be tried or punished for their participation in the armed conflict, unless their activities are war crimes in violation of the laws of war. ${ }^{42}$

Under the Geneva Convention,

an organization must meet [four criteria] for its members to qualify for lawful combatant status:

i. the organization must be commanded by a person responsible for his subordinates;

ii. the organization's members must have a fixed distinctive emblem or uniform recognizable at a distance;

36. See, e.g., Ex parte Quirin, 317 U.S. 1, 30-36 (1942); United States v. Lindh, 212 F. Supp. 2d 541, 552-58 (E.D. Va. 2002). See generally Laura A. Dickinson, Using Legal Process to Fight Terrorism: Detentions, Military Commissions, International Tribunals, and the Rule of Law, 75 S. CAL. L. REV. 1407 (2002) (discussing other treaties and principles of international law that have implications for enemy combatant detentions); Jordan J. Paust, Judicial Power to Determine the Status and Rights of Persons Detained Without Trial, 44 HARV. INT'L L.J. 503 (2003) (same).

37. See GCPW arts. 2-3.

38. See Quirin, 317 U.S. at 20-24 (seven members of German Army during World War II); Hamdi v. Rumsfeld, 316 F.3d 450, 469-77 (4th Cir. 2003) (alleged soldier for Taliban), vacated, 542 U.S. 507 (2004); Lindh, 212 F. Supp. 2d at 552-58 (same).

39. See Padilla v. Rumsfeld, 352 F.3d 695, 702-04 (2d Cir. 2003), rev'd, 542 U.S. 426 (2004).

40. See GCPW arts. 4-5, 12-17.

41. See id. art. 17.

42. See Padilla v. Bush, 233 F. Supp. 2d 564, 592 (S.D.N.Y. 2002) (citing Lindh, 212 F. Supp. 2d at 553; GCPW art. 87), aff'd in part, rev'd in part sub nom. Padilla v. Rumsfeld, 352 F.3d 695 (2d Cir. 2003), rev'd, 542 U.S. 426 (2004). 
iii. the organization's members must carry arms openly; and

iv. the organization's members must conduct their operations in accordance with the laws and customs of war. ${ }^{43}$

Individuals who do not qualify under these requirements are unlawful enemy combatants, and the capturing power is not bound by the rules of the Convention in its treatment of them. ${ }^{44}$

Unlawful enemy combatants not only may be detained, but also may be interrogated concerning any information they possess and may be "subject to trial and punishment by military tribunals for acts which render their belligerency unlawful." 45 For example, the German soldiers in the Quirin case were unlawful enemy combatants because immediately after entering the United States they discarded the uniforms and emblems that identified them as belligerents. ${ }^{46}$

The detention of lawful or unlawful combatants may continue until the end of the armed conflict, at which time prisoners of war must be repatriated. ${ }^{47}$ It is unclear whether the President's determination that an armed conflict has not yet ended would be a justiciable controversy subject to judicial review; with respect to persons associated with the Taliban or Al Qaeda, courts have refused to reach even that question on ripeness grounds. ${ }^{48}$

The Taliban military forces in Afghanistan fail all four criteria of the Convention, and the same is true of $\mathrm{Al}$ Qaeda. ${ }^{49}$ This makes it highly

43. Lindh, 212 F. Supp. 2d at 557 (citing GCPW art. 4(A)(2)).

44. See Padilla, 233 F. Supp. $2 d$ at 592-93. If the government seeks only to detain the alleged terrorist for purpose of incapacitating him from participating in planning or from committing further attacks, then it does not matter whether the person is a lawful or unlawful enemy combatant because both are subject to indefinite detention under the laws of war. See Hamdi v. Rumsfeld, 316 F.3d 450, 465-66, 469 (4th Cir. 2003), vacated, 542 U.S. 507 (2004).

45. Ex parte Quirin, 317 U.S. 1, 31 (1942); see also Padilla, 233 F. Supp. 2d at 594-93.

46. Quirin, 317 U.S. at 36-37; see also Padilla, 233 F. Supp. 2d at 594 \& n. 12.

47. See Hamdi v. Rumsfeld, 124 S. Ct. 2633, 2641 (2004) (plurality opinion); In re Territo, 156 F.2d 142, 148 (9th Cir. 1946) (noting that repatriation of Italian prisoner of war was not required because no peace treaty had yet been signed).

48. See Hamdi, $124 \mathrm{~S}$. Ct. at 2641-42 (plurality opinion); Hamdi, 316 F.3d at 476-77; Padilla, 233 F. Supp. 2d at 588-91.

49. See Padilla, 233 F. Supp. 2d at 593 (Al Qaeda) (citing Ruth Wedgwood, Al Qaeda, Terrorism, and Military Commissions, 96 AM. J. INT'L L. 328, 335 (2002) ("Al Qaeda has failed to fulfill four prerequisites of lawful belligerency.")); Lindh, 212 F. Supp. 2d at 557-58 (Taliban). But see infra notes 186-88 and accompanying text (discussing application of laws of war to terrorists). The Supreme Court in Hamdi adopted a narrower definition of an 
unlikely that an alleged terrorist could successfully pursue a claim for treatment as a lowful enemy combatant. Such a claim would fail either because the terrorist organization to which the person belongs fails the Geneva Convention criteria, or because the acts of terrorism alleged to have been carried out or planned are themselves violations of the laws of war rendering the person an unlawful belligerent, or both. Accordingly, this Article assumes that a citizen challenging his detention as an enemy combatant does not maintain that he should be designated as a lawful enemy combatant, but rather asserts the claim that he is not an unlawful combatant because he is not a combatant at all.

\section{The "War" Against Terrorism}

In the aftermath of the September 11th attacks, the federal government's antiterrorism efforts were given the rhetorical label of a "war" against terrorism. ${ }^{50}$ In addition to the established uses of domestic civilian criminal enforcement ${ }^{51}$ and foreign intelligence agencies like the CIA, the government expressly invoked its war powers in taking action against the Al Qaeda organization and its members. As part of this shift, the President designated certain individuals as enemy combatants subject to detention under military, rather than civilian, law. Although some of these persons were captured by the United States Armed Forces in zones of combat in Afghanistan, others were not-including at least two who were initially arrested by civilian law enforcement in the United States. ${ }^{52}$

unlawful enemy combatant, discussed further infra Part IV.A. See Hamdi, 124 S. Ct. at 2639 (plurality opinion).

50. Among many other instances, the President used such a label in his State of the Union address four months after the attacks. See State of the Union, supra note 1, at 134-35 (describing "war on terror" and "war against terror").

51. For example, members of the conspiracy responsible for the bombings of the United States embassies in Kenya and Tanzania in 1998 were tried in the United States District Court for the Southern District of New York. See, e.g., United States v. El-Hage, 213 F.3d 74 (2d Cir. 2000); United States v. Bin Laden, 91 F. Supp. 2d 600 (S.D.N.Y. 2000). Accused "shoe bomber," Richard Reid, likewise faced civilian charges. See United States v. Reid, 214 F. Supp. 2d 84 (D. Mass. 2002). Reid eventually pled guilty. See Pamela Ferdinand, Would-Be Shoe Bomber Gets Life Term; Al Qaeda Member Shouts at Judge, WASH. POST, Jan. 31, 2003, at $\mathrm{Al}$.

52. See, e.g., Hamdi, 316 F.3d at 460 (United States citizen initially seized in Afghanistan); Al-Marri v. Bush, 274 F. Supp. 2d 1003, 1004 (C.D. Ill. 2003) (foreign national initially arrested by FBI in Peoria, Illinois); Padilla, 233 F. Supp. 2d at 568-69 (United States citizen initially arrested by FBI in Chicago). 
This Article is not concerned directly with the specific factual or legal circumstances of these enemy combatant detentions. Instead, it analyzes the broader constitutional question of the proper scope of judicial review in a habeas corpus proceeding challenging such a detention purely on its merits - that is, when all other constitutional and statutory standards are satisfied and the only remaining question is the legitimacy of detention under the Constitution.

Nevertheless, a brief review of the government's actual practice in detaining persons as enemy combatants is necessary. First, examining the circumstances in which the issue arose, develops, and could arise again in the future are important to evaluating the constitutional standards discussed later. Second, the ongoing litigation concerning the constitutionality of this actual practice is inevitably influenced by the manner in which the detentions have been carried out, and those influences have affected the decisions the courts have reached. To properly analyze the broader theoretical questions, therefore, requires an understanding of the idiosyncrasies of actual practice.

\section{Constitutional and Statutory War Powers Relating to Detention}

The constitutional issues involving the scope and nature of the federal government's war powers in general generated an extensive range of doctrine and scholarship that is far beyond the scope of this Article ${ }^{53} \mathrm{~A}$ summary of the basic principles is helpful in examining the doctrines specifically relating to detentions, however.

The Constitution allocates powers over foreign affairs and war to the political branches. Congress has the power to declare war and to create the

53. See generally JOHN HART ELY, WAR AND RESPONSIBILITY: CONSTITUTIONAL Lessons of Vietnam and Its Aftermath (1993); LoUIS Fisher, Presidential War PoWer (2d ed. 2004); LOUIS HENKIN, ForEIGN AFFAIRS AND THE UNITED STATES CONSTITUTION (2d ed. 1996); HaROld HONGJU KOH, The National SECURITY CONSTItUTION: SHaring POWER AFTER THE IRAN-CONTRA AFFAIR (1990); H. JEFFERSON POWELL, THE PRESIDENT'S AUTHORITY OVER FOREIGN AfFaIRS (2002); Bruce Ackerman, This Is Not a War, 113 YALE L.J. 1871 (2004) (responding to David Cole, The Priority of Morality: The Emergency Constitution's Blind Spot, 113 YALE L.J. 1753 (2004) and Laurence H. Tribe \& Patrick O. Gudridge, The Anti-Emergency Constitution, 113 YALE L.J. 1801 (2004)); Michael Stokes Paulsen, The Constitution of Necessity, 79 Notre Dame L. Rev. 1257 (2004); Saikrishna Prakash, The Constitution as Suicide Pact, 79 Notre DaMe L. Rev. 1299 (2004); John C. Yoo, Judicial Review and the War on Terrorism, 72 GEO. WASH. L. REV. 427 (2003); Lori Sachs, Comment, September 11, 2001: The Constitution During Crisis: A New Perspective, 29 FordHAM URB. L.J. 1715 (2002). 
United States military. ${ }^{54}$ The President is the Commander-in-Chief of the Armed Forces and has power to repel invasions and attacks against the United States. ${ }^{55}$ The federal courts, therefore, give great deference to the actions of the political branches involving war and other use of military force abroad. ${ }^{56}$ Similarly, under the Supreme Court's famous Youngstown framework, the courts also will give more deference to the exercise of emergency powers domestically when the President acts pursuant to statutory authority from Congress than when he does not. ${ }^{57}$

Two lines of Supreme Court precedent specifically implicate war powers relating to detention of persons in military custody. Although none of these cases directly addresses the scope of judicial review of the detention of alleged enemy combatants, they nonetheless have significance for analyzing that issue. ${ }^{58}$

54. See U.S. ConST. art. I, $\S 8$, cls. 10-16.

55. See id. art. II, § 2, cl. 1; see also, e.g., The Prize Cases, 67 U.S. (2 Black) 635, 66870 (1863) (discussing presidential power to repel attacks); Campbell v. Clinton, 203 F.3d 19, 26-27 (D.C. Cir. 2000) (Silberman, J., concurring) (same).

56. See, e.g., Hamdi v. Rumsfeld, 316 F.3d 450, 462-66 (4th Cir. 2003) (citing cases), vacated, 542 U.S. 507 (2004); Hamdi v. Rumsfeld, 296 F.3d 278, 281-82 (4th Cir. 2002), rev'd, 316 F.3d 450, and vacated, 542 U.S. 507 (2004) (same).

57. See Youngstown Sheet \& Tube Co. v. Sawyer, 343 U.S. 579, 635-46 (1952) (Jackson, J., concurring) (describing deference framework); Padilla v. Rumsfeld, 352 F.3d 695, 711-12 (2d Cir. 2003), rev'd, 542 U.S. 426 (2004) (applying framework); Hamdi, 296 F.3d at 281 (same).

58. For more detailed doctrinal analyses of this precedent, see generally Roberto Iraola, Enemy Combatants, the Courts, and the Constitution, 56 OKLA. L. REv. 565 (2003); Andrew T. Jackola, A Second Bite at the Apple: How the Government's Use of the Doctrine of Enemy Combatants in the Case of Zacarias Moussaoui Threatens to Upset the Future of the Criminal Justice System, 27 HAMLINE L. REV. 101 (2004); Steven R. Swanson, Enemy Combatants and the Writ of Habeas Corpus, 35 ARIZ. ST. L. REV. 939 (2003); Carl Tobias, Detentions, Military Commissions, Terrorism, and Domestic Case Precedent, 76 S. CAL. L. REv. 1371 (2003); Michael Beattie \& Lisa Yonka Stevens, Comment, An Open Debate on United States Citizens Designated as Enemy Combatants: Where Do We Go from Here?, $62 \mathrm{MD}$. L. REV. 975 (2003); Whitney D. Frazier, Note, The Constitutionality of Detainment in the Wake of September 11th, 90 KY. L.J. 1089 (2002); Nicholas A. Kacprowski, Note, Stacking the Deck Against Suspected Terrorists: The Dwindling Procedural Limits on the Government's Power to Indefinitely Detain United States Citizens as Enemy Combantants, 26 SEATTLE U. L. REV. 651 (2003); Thomas J. Lepri, Note, Safeguarding the Enemy Within: The Need for Procedural Protections for U.S. Citizens Detained as Enemy Combatants Under Ex Parte Quirin, 71 FordhaM L. ReV. 2565 (2003); Samantha A. Pitts-Kiefer, Note, Jose Padilla: Enemy Combatant or Common Criminal?, 48 VILL. L. REv. 875 (2003); Amanda Schaffer, Comment, Life, Liberty, and the Pursuit of Terrorists: An In-Depth Analysis of the Government's Right 
One the one hand, the Supreme Court sustained the constitutionality of trials of enemy combatants by military tribunals, rather than by civilian courts. In Ex parte Quirin, the Court heard on an expedited basis petitions by six German nationals and one United States citizen challenging the President's military order designating them for trial by military tribunal for violations of the laws of war on U.S. soil during World War II. ${ }^{59} \mathrm{~A}$ unanimous Court held that the President properly invoked statutory authority granted by Congress to convene such tribunals. ${ }^{60}$ Furthermore, the Court concluded that on the "conceded facts" of the case, ${ }^{61}$ the petitioners violated the laws of war and were unlawful enemy combatants. ${ }^{62}$ Finally, the Court held that the citizen could be tried by the military tribunal as well by virtue of his status as an unlawful enemy combatant. ${ }^{63}$ On similar reasoning, the Court in Application of Yamashita upheld the conviction by military tribunal of the former Japanese commander for the Philippines. ${ }^{64}$

On the other hand, the Court has strongly suggested that it is unconstitutional to hold trials by military tribunal of civilians and other noncombatants when civilian courts are functioning. In Duncan v. Kahanamoku, the Court held that despite the existence of a state of martial law in Hawaii during World War II, civilians could not be tried for civil crimes by military tribunals. ${ }^{65}$ Because the civilian courts were open and trying cases, the civilian defendant could not be subject to military jurisdiction. ${ }^{66}$ Similarly, in

to Classify United States Citizens Suspected of Terrorism as Enemy Combatants and Try Those Enemy Combatants by Military Commission, 30 FORDHAM URB. L.J. 1465 (2003).

59. 317 U.S. 1, 18-20 (1942).

60. Id. at $26-30,47-48$.

61. Id. at 46.

62. See id. at $30-31,36-46$.

63. See id. at 37-38, 44; see also Colepaugh v. Looney, 235 F.2d 429, 431-33 (10th Cir. 1956); In re Territo, 156 F.2d 142, 142-45 (9th Cir. 1946). The Quirin Court accordingly did not address the government's claim that the petitioner's actions constituted a renunciation of his citizenship. See 317 U.S. at 20-21, 37-38.

64. See 327 U.S. 1, 5-13 (1946).

65. See 327 U.S. 304,324 (1946). The two petitioners had been convicted by military tribunals for embezzlement and assault, respectively. See id at 309-11.

66. See id. at 313-24. The Court held that the Organic Act for the territorial government of Hawaii did not authorize the use of military tribunals on the facts presented. See id. at 31324. The Court noted the significant constitutional implications of the case, but did not decide it on that basis. See id. at 319-24; see also id. at 325-35 (Murphy, J., concurring). In Ex parte Endo, the Court held that the concededly loyal habeas petitioner was improperly subject to continued military custody during the Japanese relocations; this decision also was based on statutory, not constitutional, grounds. See 323 U.S. 283, 297-304 (1944). 
the famous case of Ex parte Milligan, the Court ordered the release of the defendant tried and sentenced to death by a military tribunal during the Civil War because the prisoner was entitled to release under a controlling federal statute. ${ }^{67}$ A majority of the Court also declared that a military tribunal could not constitutionally try the defendant because he was a civilian in a state (Indiana) that had not seceded and where the civilian courts were open and functioning. ${ }^{68}$

These cases do not resolve the issue of the government's burden of proof in a case in which the prisoner's status is contested. In Quirin and Yamashita, the prisoners were indisputably enemy combatants; in Duncan and Milligan, the prisoners were concededly civilians. ${ }^{69}$ Thus, the fundamental constitutional issue the scope of judicial review in a contested case-remains unresolved.

In addition to these constitutional doctrines, a federal statute limits the power of the President to detain citizens as enemy combatants. The NonDetention Act, also referred to as $\S 4001$ (a), provides as follows: "No citizen shall be imprisoned or otherwise detained by the United States except pursuant to an Act of Congress. ${ }^{, 70}$ Enacted in 1971 to repeal a prior statute authorizing broad domestic detention authority in times of war, ${ }^{71}$ the Non-

67. See 71 U.S. 2, 107-08, 115-16 (1866); see also Ex parte Merryman, 17 F. Cas. 144, 147-48, 150 (C.C.D. Md. 1861) (No. 9487).

68. See Milligan, 71 U.S. at 107-08, 118-27. The concurring Justices agreed Milligan was entitled to release under the statute, see id. at 130-31, but argued that Congress had the constitutional power to declare martial law even in loyal states, in which case a trial by military tribunal would be constitutional, see id. at 136-37. The Court in Quirin expressly distinguished Milligan on the grounds that Milligan was a non-belligerent, unlike the petitioners in Quirin. See 317 U.S. at 45-46.

69. The Supreme Court in Hamdi adopted this interpretation of Quirin and Milligan in upholding the government's authority to detain as enemy combatants citizens who qualify as belligerents under the laws of war. See Hamdi v. Rumsfeld, 124 S. Ct. 2633, 2642-43 (2004); $i d$. at 2682 (Thomas, J., dissenting). Justice Scalia argued that Milligan should control Hamdi's case and that Quirin should not be followed. See id. at 2668-70 (Scalia, J., dissenting). For similar critiques of Quirin, see A. Christopher Bryant \& Carl Tobias, Quirin Revisited, 2003 WiS. L. REV. 309, 330-31; Tobias supra note 58, at 1398-1401.

70. 18 U.S.C. $\S 4001$ (a) (2000). For thorough analysis of the Act, see generally Stephen I. Vladeck, Note, The Detention Power, 22 YALE L. \& POL'Y REv. 153 (2004); Stephen I. Vladeck, Policy Comment, A Small Problem of Precedent: 18 U.S.C. $\S 4001$ (a) and the Detention of U.S. Citizen "Enemy Combatants," 112 Yale L.J. 961 (2003).

71. See Hamdi, 124 S. Ct. at 2653-55 (Souter, J., concurring) (reviewing enactment and legislative history of Non-Detention Act); Padilla v. Rumsfeld, 352 F.3d 695, 718-22 (2d Cir. 2003) (same), rev'd, 542 U.S. 426 (2004). 
Detention Act would preclude the detention of United States citizens as enemy combatants absent congressional approval. ${ }^{72}$

\section{Responses to the September 11 th Attacks}

On the morning of September 11, 2001, nineteen members of the Al Qaeda terrorist organization hijacked four commercial airliners nearly simultaneously. Two were crashed into the World Trade Center towers in New York City, which were destroyed. The third was flown into the Pentagon in Washington, and the fourth crashed in a field in rural Pennsylvania after the passengers turned against the hijackers. Approximately 3000 persons were killed in the attacks, and billions of dollars in property damage and economic effects resulted. ${ }^{73}$

On September 14, 2001, the President signed a proclamation entitled "Declaration of National Emergency by Reason of Certain Terrorist Attacks" to declare a national emergency and to invoke a number of statutory emergency powers. $^{74}$

Four days later, Congress enacted a Joint Resolution authorizing the President to take military action by using

72. Compare Hamdi, $124 \mathrm{~S}$. Ct. at 2653-57 (Souter, J., concurring) (finding lack of congressional approval for detention); id. at $2671-72$ (Scalia, J., dissenting) (same); Padilla, 352 F.3d at 718-24 (same), with Hamdi, $124 \mathrm{~S}$. Ct. at 2639-41 (plurality opinion) (finding congressional approval); id. at 2678-80 (Thomas, J., dissenting) (same); Padilla, 352 F.3d at 726-32 (Wesley, J., dissenting) (same); Hamdi v. Rumsfeld, 316 F.3d 450, 467-68 (4th Cir. 2003) (same), vacated, 542 U.S. 507 (2004); Padilla ex rel. Newman v. Bush, 233 F. Supp. $2 d$ 564, 596-99 (S.D. N.Y. 2002) (same), aff'd in part and rev'd in part sub nom. Padilla v. Rumsfeld, 352 F.3d 695, rev'd, 542 U.S. 426 (2004). The Act potentially could bar the detention of a citizen even on a foreign battlefield, which might interfere with the President's constitutional powers in foreign, rather than domestic, affairs. Compare Hamdi, 316 F.3d at 468 ("There is no indication that $\$ 4001$ (a) was intended to overrule the longstanding rule that an armed and hostile American citizen captured on the battlefield during wartime may be treated like the enemy combatant that he is."), with Padilla, 352 F.3d at 721 \& n.29 ("[T] President, acting alone, possesses no inherent constitutional authority to detain American citizens seized within the United States, away from a zone of combat, as enemy combatants ... it might have been preferable to hold that Congress could not intrude on the President's Commander-in-Chief power on the battlefield rather than to interpret the Act as the Fourth Circuit did.").

73. See, e.g., Hamdi v. Rumsfeld, 124 S. Ct. 2633, 2635-37 (2004) (plurality opinion); Hamdi, 316 F.3d at 459; Padilla, 233 F. Supp. 2d at 570.

74. See Proclamation 7463, 66 Fed. Reg. 48199 (Sept. 14, 2001). 
all necessary and appropriate force against those nations, organizations, or persons he determines planned, authorized, committed, or aided the terrorist attacks that occurred on September 11,2001, or harbored such organizations or persons, in order to prevent any future acts of international terrorism against the United States by such nations, organizations or persons. ${ }^{75}$

Pursuant to this authority, the President deployed United States military forces to Afghanistan against Al Qaeda agents and the Taliban regime that supported them. ${ }^{76}$ The President also relied on the Joint Resolution as a source of congressional approval for the detention of alleged terrorists as enemy combatants. ${ }^{77}$

On October 26, 2001, Congress passed the notorious "USA PATRIOT Act" to enact a wide range of antiterrorism measures. ${ }^{78}$ Among other changes, the Act expanded criminal offenses relating to terrorism and money laundering, amended the Foreign Intelligence Surveillance Act and the Federal Rules of Criminal Procedure governing secrecy of grand jury investigations, and authorized greater search and surveillance powers in criminal investigations. ${ }^{79}$ The Patriot Act did not specifically authorize military tribunals or enemy combatant detentions, however.

In addition to these congressional actions, the President declared his willingness to use military tribunals, rather than civilian courts, to hold trials of alleged terrorists. On November 13, 2001, the President signed a Military Order authorizing the Secretary of Defense to detain alleged terrorists and

75. Authorization for Use of Military Force, Pub. L. No. 107-40, 115 Stat. 224 (2001) (emphasis added). The President signed the resolution the same day. See Padilla, 233 F. Supp. at 570 \& n. 3 .

76. See, e.g., Hamdi, 124 S. Ct. at 2635-37 (plurality opinion); Rasul v. Bush, 124 S. Ct. 2686, 2690 (2004); Hamdi, 316 F.3d at 459-60.

77. See text accompanying infra notes $92,106$.

78. See Uniting and Strengthening America by Providing Appropriate Tools Required to Intercept and Obstruct Terrorism Act of 2001, Pub. L. No. 107-56, 115 Stat. 272 (2001).

79. See id. $\S \S$ 201-220; In re Sealed Case, 310 F.3d 717, 728-36 (FISA Ct. Rev. 2002) (interpreting amendment to FISA); COLE \& DEMPSEY, supra note 3, at 151-75 (criticizing numerous amendments included in Act); Sara Sun Beale \& James E. Felman, The Consequences of Enlisting Federal Grand Juries in the War on Terrorism: Assessing the USA PATRIOT Act's Changes to Grand Jury Secrecy, 25 HARV. J.L. \& PuB. POL'Y 699, 708-09 (2002) (discussing amendment to Federal Rule of Criminal Procedure 6(e)). See generally Broad Anti-Terrorism Package Passed by Congress, Signed by President, 70 BNA CRIM. L. REP. 93 (Oct. 31, 2001) (summarizing provisions of Act). 
convene military tribunals to try them. ${ }^{80}$ The persons subject to the military order were "any individual who is not a citizen of the United States" who the President has "reason to believe" is a member of Al Qaeda or is otherwise an accomplice or conspirator in international terrorism against the United States. ${ }^{81}$ Subsequently, the Department of Defense promulgated regulations governing the military tribunals, including provisions relating to offenses subject to trial, military and civilian defense counsel, admission of evidence, trial procedures, and sentencing. ${ }^{82}$ These actions by the President and the Department of Defense have generated a substantial body of scholarship. ${ }^{83}$

80. See Military Order, Detention, Treatment, and Trial of Certain Non-Citizens in the War Against Terrorism, 66 Fed. Reg. 57,833 (Nov. 16, 2001).

81. See id. at 57,834 .

82. See Military Commission Order No. 1 (Mar. 21, 2002); Military Commission Instructions Nos. 1-8 (Apr. 30, 2003).

83. See generally AM. BAR ASS'N, TASK FORCE ON TERRORISM AND THE LAW, REPORT AND RECOMMENDATIONS ON MILITARY COMMISSIONS (Jan. 4, 2002); Gerard J. Clark, Military Tribunals and the Separation of Powers, 63 U. PITT. L. REV. 837 (2002); Jack Goldsmith \& Cass Sunstein, Military Tribunals and Legal Culture: What a Difference Sixty Years Makes, 19 CONST. COMMENT. 261 (2002); Michael J. Matheson, U.S. Military Commissions: One of Several Options, 96 AM. J. INT'L L. 354 (2002).

For scholarship supporting the use of military tribunals to try terrorists, see generally Kenneth Anderson, What to Do with bin Laden and Al Qaeda Terrorists?: A Qualified Defense of Military Commissions and United States Policy on Detainees at Guantanamo Bay Naval Base, 25 HARV. J.L. \& PUB. POL'Y 591 (2002); Robert John Araujo, A Judicial Response to Terrorism: The Status of Military Commissions Under Domestic and International Law, 11 TUL. J. INT'L \& COMP. L. 117 (2003); John M. Bickers, Military Commissions Are Constitutionally Sound: A Response to Professors Katyal and Tribe, 34 TeX. TeCh L. REV, 899 (2003); Curtis A. Bradley \& Jack L. Goldsmith, The Constitutional Validity of Military Commissions, 5 GREEN BAG 2D 249 (2002); Roberto Iraola, Military Tribunals, Terrorists, and the Constitution, 33 N.M. L. REv. 95 (2003); Wedgwood, supra note 49; Keith S. Alexander, Note, In the Wake of September 1lth: The Use of Military Tribunals to Try Terrorists, 78 NOTRE DAME L. REv. 885 (2003).

For scholarship opposing military tribunals, see generally Adeno Addis, Strangers to the Constitution?: Resident Aliens, Military Tribunals, and the Laws of War, 37 VAL. U. L. REV. 627 (2003); Michael R. Belknap, A Putrid Pedigree: The Bush Administration's Military Tribunals in Historical Perspective, 38 CAL. W. L. REv. 433 (2002); Dickinson, supra note 36; Joan Fitzpatrick, Jurisdiction of Military Commissions and the Ambiguous War on Terrorism, 96 AM. J. INT'L L. 345 (2002); George P. Fletcher, On Justice and War: Contradictions in the Proposed Military Tribunals, 25 HARV. J.L. \& PUB. POL'Y 635 (2002); David L. Herman, A Dish Best Not Served At All: How Foreign Military War Crimes Suspects Lack Protection Under United States and International Law, 172 ML. L. REV. 40 (2002); Neal K. Katyal \& Laurence H. Tribe, Waging War, Deciding Guilt: Trying the Military Tribunals, 111 YALE L.J. 1259 (2002); Harold Hongju Koh, The Case Against Military 
As of February 2005, no person has yet been tried by a military tribunal pursuant to this authority, although several captured leaders of Al Qaeda ultimately may be tried. ${ }^{84}$ Several hundred persons remain detained pursuant

Commissions, 96 AM. J. INT'L L. 337 (2002); Wayne McCormack, Military Detention and the Judiciary: Al Qaeda, the KKK, and Supra-State Law, 5 SAN DiEGo INT'L L.J. 7 (2004); Daryl A. Mundis, The Use of Military Commissions to Prosecute Individuals Accused of Terrorist Acts, 96 AM. J. INT'L L. 320 (2002); Diane F. Orentlicher \& Robert Kogod Goldman, When Justice Goes to War: Prosecuting Terrorists Before Military Commissions, 25 HARV. J.L. \& PUB. POL'Y 653 (2002); Jordan J. Paust, Antiterrorism Military Commissions: Courting Illegality, 23 MICH. J. INT'L L. 1 (2001); Jordan J. Paust, Detention, Judicial Review of Detention, and Due Process During Prosecution, 97 AM. SOC'Y INT'L L. Proc. 13 (2003) [hereinafter Paust, Detention]; Charles V. Pena, Blowback: The Unintended Consequences of Military Tribunals, 16 Notre Dame J.L. ETHICs \& PUB. Pol'Y 119 (2002); Michael Ratner, Moving Away from the Rule of Law: Military Tribunals, Executive Detentions, and Torture, 24 CARDozo L. REv. 1513 (2003); Anne-Marie Slaughter, Beware the Trumpets of War: A Response to Kenneth Anderson, 25 HARV. J.L. \& PUB. POL'Y 965 (2002); Tobias, supra note 58; Carl Tobias, Punishment and the War on Terrorism, 6 U. PA. J. CONST. L. 1116 (2004); Jennifer Trahan, Trying a Bin Laden and Others: Evaluating the Options for Terrorist Trials, 24 Hous. J. INT'L L. 475 (2002); Juan R. Torruella, On the Slippery Slopes of Afghanistan: Military Commissions and the Exercise of Presidential Power, 4 U. PA. J. CONST. L. 648 (2002); Wedgwood supra note 49; Ryan H. Beery, Comment, Modern Use of Military Tribunals: A Legal "Can" and a Political "Should"?, 28 OHO N.U. L. REv. 789 (2002); Jim Davis, Note, A Cautionary Tale: Examining the Use of Military Tribunals by the United States in the Aftermath of the September 11th Attacks in Light of Peru's History of Human Rights Abuses Resulting from Similar Measures, 31 GA. J. INT'L \& COMP. L. 423 (2003); Christopher M. Evans, Note, Terrorism on Trial: The President's Constitutional Authority to Order the Prosecution of Suspected Terrorists by Military Commission, 51 DUKE L.J. 1831 (2002); Anne English French, Note, Trials in Times of War: Do the Bush Military Commissions Sacrifice Our Freedoms?, 63 Oнго ST. L.J. 1225 (2002); David Glazier, Note, Kangaroo Court or Competent Tribunal? Judging the 2lst Century Military Commission, 89 VA. L. REv. 2005 (2003); Heather Anne Maddox, Comment, After the Dust Settles: Military Tribunal Justice for Terrorists After September 11, 2001, 28 N.C. J. INT'L L. \& CoM. REG. 421 (2002); Kathleen M. McCarroll, Comment, With Liberty and Justice for All: The November 13, 2001 Military Order Allowing the Use of Military Tribunals to Try Those Suspected of Aiding Terrorists Violates the Rights Guaranteed to Non-Citizen United States Residents Under the Constitution, 80 U. DET. MERCY L. REv. 231 (2003); Schaffer, supra note 58; Nicholas Stephanopoulos, Comment, Solving the Due Process Problems with Military Commissions, 114 YALE L.J. 921 (2005).

84. See John Mintz, U.S. Charges 2 as Bin Laden Aides, WASH. PosT, Feb. 25, 2004, at A01 (reporting that two alleged bodyguards of Osama bin Laden will be tried by military tribunals for war crimes); Reuters, Pentagon Appoints Officers for First Tribunal; No Date Set, WASH. POST, June 30, 2004, at A6; News Release, United States Department of Defense, Presidential Military Order Applied to Nine More Combatants (July 7, 2004), available at $\mathrm{http} / / / \mathrm{www}$.defenselink.mil/releases/2004/nr20040707-0987.html ("This brings to 15 the 
to the Military Order, however, principally at Guantanamo Bay naval base. ${ }^{85}$ The President's Military Order continues to provide that United States citizens will not be tried by military tribunals. ${ }^{86}$

\section{Litigation Concerning the Detention of Enemy Combatants}

The President's detention of alleged terrorists as enemy combatants has been challenged in a number of habeas corpus proceedings. Only two cases, Hamdi and Padilla, involved United States citizens. ${ }^{87}$

number of detainees that the President has determined are subject to his military order."). Four persons have been indicted pursuant to the military tribunals' rules of procedure, but since August 2004, each case remains in pretrial proceedings. See News Release, United States Department of Defense, Fourth Military Commission Concludes Week of Trials (Aug. 27, 2004), available at http://www.defenselink.mil/releases/2004/nr20040827-1180.html. On November 8, 2004, a United States district court judge ruled that the military tribunals were unlawful and granted a petition for writ of habeas corpus by one of the defendants. See Hamdan v. Rumsfeld, 344 F. Supp. 2d 152, 155 (D.D.C. 2004), rev'd, 415 F.3d 33 (D.C. Cir 2005).

85. See Rasul v. Bush, 124 S. Ct. 2686, 2690-92 (2004); Associated Press, U.S. Releases 26 Guantanamo Detainees, WASH. POST, Mar. 16, 2004, at A2 (reporting that "about 610 " persons are detained at the base and that the government has released 119 and transferred twelve); John Mintz, U.S. Outlines Plan for Detainee Review, WASH. PosT, Mar. 4, 2004, at A10 (reporting that "about 650 " persons are detained at the base). After the Rasul decision, the government announced that the Guantanamo detainees would receive a review of their status in a military proceeding. See Josh White, U.S. to Tell Detainees of Rights; Pentagon Outlines New Procedures, WASH. POsT, July 10, 2004, at A07; News Release, United States Department of Defense, Combatant Status Review Tribunal Order Issued (July 7, 2004), available at http://www.defenselink.mil/releases/2004/nr20040707-0992.html. The first hearings took place in December 2004. See News Release, United States Department of Defense, Defense Department Conducts First Administrative Review Board (Dec. 14, 2004), available at http://www.defenselink.mil/releases/2004/nr20041214-1830.html. On January 31, 2005, a United States district court judge ruled that the procedures provided in the hearings were unconstitutional. See In re Guantanamo Detainee Cases, 355 F. Supp. 2d 443, 468 (D.D.C. 2005) (holding that Combatant Status Review tribunals violated Due Process Clause).

86. See Military Order, supra note 80 , at 57,834 .

87. Several actions were instituted concerning the detention of foreign nationals at the naval base at Guantanamo Bay, Cuba. In the lower courts, these cases addressed only the question of the courts' subject-matter jurisdiction over the petitions. See Al Odah v. United States, 321 F.3d 1134, 1142-45 (D.C. Cir. 2003), aff'g Rasul v. Bush, 215 F. Supp. 2d 55 (D.D.C. 2002); Gherebi v. Bush, 262 F. Supp. 2d 1064, 1065-69 (C.D. Cal. 2003), rev'd, 352 F.3d 1278 (9th Cir. 2003); Coal. of Clergy v. Bush, 189 F. Supp. 2d 1036, 1046-50 (C.D. Cal. 2002), vacated in relevant part sub. nom. Coal. of Clergy, Lawyers, \& Professors v. Bush, 310 F.3d 1153, 1164 (9th Cir. 2002). The Supreme Court granted certiorari in the Rasul-Al Odah 
Yaser Hamdi was a United States citizen detained as an enemy combatant at the navy brig in Norfolk, Virginia. ${ }^{88}$ Hamdi apparently was taken into custody by the United States military in Afghanistan in late 2001; he subsequently was transferred in early 2002 to the detention facilities at Guantanamo Bay naval base and then, when it was determined he might be a citizen, to Norfolk. ${ }^{89}$ In the habeas proceeding, the district court initially ordered that counsel be given unmonitored access to Hamdi, but the Fourth Circuit stayed and ultimately overruled those orders for having given insufficient consideration to the government's interests. ${ }^{90}$ The district court then ruled that the government's sole evidence-a so-called "Mobbs Declaration" by a Special Advisor in the Department of Defense which classified Hamdi as an enemy combatant based on his "affiliation" with Taliban military forces in Afghanistan-was insufficient to justify the detention of Hamdi as an enemy combatant. ${ }^{91}$

The Fourth Circuit once again reversed, holding that the detention of enemy combatants falls squarely within the Constitution's war powers and that the Joint Resolution constituted sufficient congressional authority under the Non-Detention Act. ${ }^{92}$ The Court of Appeals further concluded that the Mobbs Declaration provided a sufficient factual basis to justify detention of Hamdi as an enemy combatant in light of concessions in the petition that left the fact of Hamdi's seizure in a foreign zone of combat undisputed. ${ }^{93}$

case, see Rasul v. Bush, 124 S. Ct. 534 (2003); Al Odah v. United States, 124 S. Ct. 534 (2003), and ultimately ruled that subject-matter jurisdiction existed, see Rasul v. Bush, 124 S. Ct. 2686 (2004). This issue is reviewed briefly infra note 165.

For more detailed doctrinal analyses of the Hamdi, Padilla, and Guantanamo litigation, see generally Iraola, supra note 58; Jackola, supra note 58; Kacprowski, supra note 58; Lepri, supra note 58; Schaffer, supra note 58.

88. See Hamdi v. Rumsfeld, 124 S. Ct. 2633, 2635-37 (2004) (plurality opinion); Hamdi v. Rumsfeld, 316 F.3d 450, 459-62 (4th Cir. 2003), vacated, 542 U.S. 507 (2004); Hamdi v. Rumsfeld, 296 F.3d 278, 280-81 (4th Cir. 2002), rev'd, 316 F.3d 450 (4th Cir. 2003), vacated, 542 U.S. 507 (2004); Hamdi v. Rumsfeld, 294 F.3d 598, 601 (4th Cir. 2002), rev'd, 316 F.3d 450 (4th Cir. 2003), vacated, 542 U.S. 507 (2004).

89. See Hamdi, 124 S. Ct. at 2635-37; Hamdi, 316 F.3d at 459-62; Hamdi, 296 F.3d at 280-81; Hamdi, 294 F.3d at 601.

90. See Hamdi, 296 F.3d at 280-83; Hamdi, 294 F.3d at 602.

91. See Hamdi v. Rumsfeld, 243 F. Supp. 2d 527, 532-36 (E.D. Va. 2002), rev'd, 316 F.3d 450 (4th Cir. 2003), vacated, 542 U.S. 507 (2004).

92. See Hamdi, 316 F.3d at $462-69$.

93. See id. at 469-77. On petition for rehearing en banc, two judges disputed whether the petition in fact conceded the dispositive facts. See Hamdi v. Rumsfeld, 337 F.3d 335, 34557 (4th Cir. 2003) (Traxler, J., concurring), vacated, 542 U.S. 507 (2004); id. at 357-68 
The United States Supreme Court granted Hamdi's petition for certiorari $^{94}$ and in a heavily divided opinion, vacated the Fourth Circuit's ruling. ${ }^{95}$ Although the Court was unanimous that Congress had not suspended the writ of habeas corpus, the Justices agreed on little else. ${ }^{96}$ Five Justices concluded that the Joint Resolution constituted congressional authorization for enemy combatant detentions, while the remaining four argued that the President lacked the power to order such detentions. ${ }^{97}$ Eight Justices concluded that Hamdi's detention was unconstitutional, but no opinion garnered a majority. ${ }^{98}$ At least six Justices determined that Hamdi had a right of access to counsel in contesting the government's allegations that he is an enemy combatant. ${ }^{99}$ Finally, the plurality opinion rejected the Fourth Circuit's assertion that Hamdi's petition had conceded his status as an enemy combatant ${ }^{100}$ and found that the government's proffered evidence was insufficient. ${ }^{101}$ The Court remanded the case for further proceedings regarding the constitutionality of Hamdi's detention as an enemy combatant. ${ }^{102}$

José Padilla was a United States citizen detained as an enemy combatant at the navy brig in Charleston, South Carolina. ${ }^{103}$ Pursuant to a material witness warrant issued by a federal district court in New York, Padilla was

(Luttig, J., dissenting). One judge wrote in agreement with the district court's conclusion that the Mobbs Declaration was insufficient. See id. at 368-76 (Motz, J., dissenting); cf. id. at 34145 (Wilkinson, J., concurring) (responding to arguments).

94. See Hamdi v. Rumsfeld, 124 S. Ct. 981 (2004).

95. See Hamdi v. Rumsfeld, 124 S. Ct. 2633 (2004).

96. See id. at 2644 (plurality opinion); id. at 2664-65 (Scalia, J., dissenting); id. at 2683 (Thomas, J., dissenting).

97. Compare id. at 2639-41 (plurality opinion) (finding congressional authorization), and id. at 2678-80 (Thomas, J., dissenting), with id. at 2653-57 (Souter, J., concurring) (rejecting congressional authorization), and id. at 2671-72 (Scalia, J., dissenting).

98. See id. at 2645-50 (plurality opinion); id. at 2660 (Souter, J., concurring); id. at 2672 (Scalia, J., dissenting). But see id. at 2680-83 (Thomas, J., dissenting).

99. See id. at 2652 (plurality opinion); id. at 2660 (Souter, J., concurring). But see id. at 2683-84, $2685 \mathrm{n} .7$ (Thomas, J., dissenting).

100. See id. at $2644-45$.

101. See id. at $2637,2645$.

102. See id. at 2652 (plurality opinion); see also id. at 2660 (Souter, J., concurring); Rumsfeld v. Padilla, 124 S. Ct. 2711, 2735 \& n.9 (2004) (Stevens, J., dissenting).

103. See Padilla v. Rumsfeld, 352 F.3d 695, $699-702$ (2d Cir. 2003), rev'd, 542 U.S. 426 (2004); Padilla ex rel. Newman v. Bush, 233 F. Supp. 2d 564, 569-74 (S.D.N.Y. 2002), aff'd in part and rev'd in part sub nom. Padilla v. Rumsfeld, 352 F.3d 695 (2d Cir. 2003), rev'd, 542 U.S. 426 (2004). 
arrested by the FBI on May 8, 2002, at O'Hare International Airport in Chicago when he returned to the United States from Pakistan. ${ }^{104}$ On June 9, two days before a scheduled hearing on Padilla's motion to quash the warrant, the President designated Padilla as an enemy combatant, and Padilla was taken into military custody. ${ }^{105}$ In the ensuing habeas proceeding, the district court concluded that the President has constitutional power to detain Padilla as an enemy combatant and that the Joint Resolution satisfied the Non-Detention Act. ${ }^{106}$ The court further ruled that Padilla had a right to present facts and to contest the government's allegations in another "Mobbs Declaration" that Padilla was acting under the direction of senior Al Qaeda operatives in researching and planning a plot to explode a "dirty bomb" in the United States or in other terrorist activities. ${ }^{107}$ The court concluded that in the interests of justice counsel was necessary to assist Padilla in pursuing the petition $^{108}$ and held that on the merits of the petition, the government's burden of proof was to establish "some evidence" justifying the designation of Padilla as an enemy combatant. ${ }^{109}$

On appeal, a panel of the Second Circuit reversed, emphasizing that the case involved "an American citizen arrested in the United States, not on a foreign battlefield or while actively engaged in armed conflict against the United States" and holding "that the President lacks inherent constitutional authority as Commander-in-Chief to detain American citizens on American soil outside a zone of combat." ${ }^{, 10}$ For the same reasons, the court of appeals held that the Non-Detention Act barred Padilla's detention because the Joint Resolution could not be construed to authorize a detention in these domestic, non-combat circumstances. ${ }^{111}$ One judge dissented on both grounds, while strongly criticizing the government's handling of Padilla's detention. ${ }^{112}$ Those rulings mooted the issues of Padilla's ability to pursue the petition or the government's burden of proof, and the Second Circuit ordered that a writ

104. See Padilla, 352 F.3d at 699-702; Padilla, 233 F. Supp. 2d at 569-74.

105. See Padilla, 352 F.3d at 699-702; Padilla, 233 F. Supp. 2d at 569-74.

106. See Padilla, 233 F. Supp. 2d at 588-99.

107. See id. at 608.

108. See id. at 572-73, 599-605; see also Padilla, 352 F.3d at 724-25 (President's order designating Padilla as enemy combatant).

109. See Padilla, 233 F. Supp. 2d at 605-08.

110. Padilla, 352 F.3d at 711-12; see also id. at 715 n.24, 718 n.27 (emphasizing lack of imminent danger of terrorist attack at time of Padilla's designation). The court distinguished Quirin and other cases as inapplicable on the facts. See id. at 710-18.

111. See id. at 718-24.

112. See id. at 726-33 (Wesley, J., dissenting). 
of habeas corpus issue, directing that Padilla be released from military custody. ${ }^{113}$

The Supreme Court granted the government's petition for certiorari, ${ }^{114}$ and it reversed the Second Circuit's ruling without reaching the merits of the case. ${ }^{115}$ By a 5-4 majority, the Court held that Padilla's petition should have been filed in South Carolina, where he was being held at the Charleston navy brig, rather than in New York, where he was incarcerated prior to being designated as an enemy combatant. ${ }^{116}$ Accordingly, the Court ordered the petition dismissed without prejudice due to lack of habeas corpus jurisdiction. ${ }^{117}$

Hamdi was held incommunicado for approximately two-and-a-half years until he was permitted to meet with counsel under strictly controlled circumstances on February 3, 2004. ${ }^{118}$ After being taken into military custody on June 9, 2002, Padilla was held incommunicado until March 3, 2004, when he met with counsel under similar strict conditions. ${ }^{119}$ Following the Supreme Court decisions regarding his case, Hamdi was released and repatriated to Saudi Arabia in October 2004, pursuant to an agreement that he renounce his United States citizenship. ${ }^{120}$ As of February 2005, Padilla remains detained as an enemy combatant, and a new habeas petition challenging that detention is now pending in the District of South Carolina. ${ }^{12}$

113. See id. at $699 \&$ n.1, 724 (majority opinion). The Second Circuit subsequently stayed its order pending the government's petition for certiorari. See Reuters, Appeals Court Stays Order to Free Padilla, WASH. POST, Jan. 23, 2004, at A2.

114. See Rumsfeld v. Padilla, 124 S. Ct. 1353 (2004).

115. See Rumsfeld v. Padilla, 124 S. Ct. 2711 (2004).

116. See id. at 2722-25.

117. See id. at 2727; id. at 2727-28 (Kennedy, J., concurring); id. at 2734-35 (Stevens, J., dissenting).

118. See Hamdi v. Rumsfeld, 124 S. Ct. 2633, 2652 (2004) (plurality opinion); Jerry Markon, Terror Suspect, Attorneys Meet for Ist Time, WASH. Post, Feb. 4, 2004, at B3.

119. See Rumsfeld, 124 S. Ct. at 2735 (Stevens, J., dissenting); Michael Powell, Lawyer Visits "Dirty Bomb" Suspect, WASH. Post, Mar. 4, 2004, at A10.

120. See Joel Brinkely, From Afghanistan to Saudi Arabia, via Guantanamo, N.Y. TIMES, Oct. 16, 2004, at A4; Jerry Markon, Father Denounces Hamdi's Imprisonment; Son Posed No Threat to U.S., He Says, WASH. Post, Oct. 13, 2004, at A4.

121. See Petition for a Writ of Habeas Corpus, Padilla v. Hanft, No. 2:04-CV-2221 (D.S.C. July 2, 2004), available at http://www.scd.uscourts.gov/padilla/docket.asp. On February 28, 2005, the district court granted Padilla's petition and ordered him released within forty-five days. Memorandum Opinion and Order, Padilla v. Hanft, No. 2:04-CV-221, 2005 WL 465691 , at *13 (D.S.C. Feb. 28, 2005). 


\section{The Open Questions About Judicial Review of Enemy Combatant Detentions}

Within this framework of doctrines regarding civilian and military detentions and the federal government's war powers are several significant open questions of constitutional law concerning the scope of judicial review of enemy combatant detentions. These questions are of fundamental importance, but they have not yet been answered in the course of actual governmental conduct. In particular, federal courts decide the cases before them, not issues of constitutional law in the abstract. ${ }^{122}$ For example, neither the Fourth Circuit in Hamdi nor the Second Circuit in Padilla reached the question of the appropriate burden of proof the government must satisfy to detain a United States citizen as an enemy combatant-the former by ruling that status was conceded, the latter by holding the President lacked the asserted power regardless of the evidence. ${ }^{123}$ The Supreme Court in Hamdi likewise failed to issue specific procedural rulings on the nature and the scope of the habeas proceeding on remand. ${ }^{124}$ Thus, addressing the fundamental open questions requires setting aside the numerous factual complexities of past and present litigation.

The analysis to follow in this Article assumes that the federal government is asserting its maximum possible war powers under the Constitution. For purposes of clarity, suppose that Congress enacts and the President signs a statute providing the following:

The President may by written declaration designate any person, regardless of citizenship, as an enemy combatant engaged in armed conflict against the United States. As the President determines best serves the interests of the United States, in accordance with the laws of war and notwithstanding any other provision of law or treaty, such persons may be: (i) detained in military custody for the duration of the conflict, (ii) interrogated, and (iii) tried and

122. The Constitution precludes federal courts from issuing advisory opinions. See Clinton v. Jones, 520 U.S. 681,700 \& n.33 (1997).

123. See Hamdi v. Rumsfeld, 316 F.3d 450, $459-61$ (4th Cir. 2003), vacated, 542 U.S. 507 (2004); Padilla v. Rumsfeld, 352 F.3d 695, 699 (2d Cir. 2003), rev'd, 542 U.S. 426 (2004).

124. See Hamdi v. Rumsfeld, 124 S. Ct. 2633, $2645-49$ (2004) (plurality opinion); id. at 2660 (Souter, J., concurring); id. at 2672 (Scalia, J., dissenting); Rumsfeld, 124 S. Ct. at 2735 (Stevens, J., dissenting). 
punished for violations of the laws of war by such military tribunals as the President shall duly constitute.

In addition, the analysis assumes that the section of the Constitution providing for suspension of the writ of habeas corpus has not been exercised, making it unnecessary to determine whether the scope of that power is a justiciable controversy. ${ }^{125}$

The analysis also presumes that a petition for a writ of habeas corpus is filed to seek judicial review of the designation of a person as an enemy combatant pursuant to this statutory authority and that the petition contests that designation on the facts. It further presumes that the petition is filed while the person is detained on the basis of the President's declaration, not the judgment of a military tribunal. ${ }^{126}$

Under these assumptions, the facts and procedural postures that existed in cases like Quirin, Yamashita, Hamdi, and Padilla that prevented the courts from reaching the fundamental open questions are not present. The government's constitutional powers to detain persons as enemy combatants are at the maximum in the Youngstown analytical scheme. ${ }^{127}$ Those powers have been invoked and are being challenged to the fullest by the detainee. Consequently, the difficult open questions of habeas corpus procedure and constitutional law can be confronted directly.

First, the analysis discusses the procedural thresholds to a petition for a writ of habeas corpus challenging an enemy combatant detention. This

125. See U.S. ConST. art. I, § 9, cl. 2; Hamdi, 124 S. Ct. at 2674 (Scalia, J., dissenting) (suggesting that congressional suspension of writ would not be judicially reviewable), $i d$. at 2683 n.4 (Thomas, J., dissenting) (same); see also INS v. St. Cyr, 533 U.S. 289, 300-05 (2001) (construing statute to avoid Suspension Clause concerns); Felker v. Turpin, 518 U.S. 651, 663-64 (1996) (finding no Suspension Clause violation); cf. Ex parte McCardle, 74 U.S. 506, 507-08, 514-15 (1868) (upholding constitutionality of statute depriving Supreme Court of appellate jurisdiction in habeas cases).

126. The caveat in the text is necessary because the scope of judicial review of judgments of military tribunals is unclear. See generally George Rutherglen, Structural Uncertainty over Habeas Corpus \& the Jurisdiction of Military Tribunals, 5 GREEN BAG 2D 397 (2002); see also In re Yamashita, 327 U.S. 1, 8 (1946) (post-judgment challenge); Ex parte Quirin, 317 U.S. 1 (1942) (pretrial challenge); Ex parte Vallandingham, 68 U.S. 243, 251 (1863) (post-judgment challenge). Federal courts hearing habeas petitions perform only limited review of judgments of courts martial under the Uniform Code of Military Justice. See, e.g., Burns v. Wilson, 346 U.S. 137, 144 (1953); Khan v. Hart, 943 F.2d 1261, 1262 (10th Cir. 1991); Dodson v. Zelez, 917 F.2d 1250, 1252-53 (10th Cir. 1990).

127. See supra note 57 and accompanying text. 
involves consideration of the proper parties and the proper district in which the petition may be filed. In addition, the analysis examines the subjectmatter jurisdiction of the federal courts over such petitions. Because the writ can be issued only to terminate custody that violates the Constitution, ${ }^{128}$ the petitioner must be a person who possesses constitutional rights that the government is obligated to respect. Although much of this law is clear, there remain unresolved issues.

Second, the analysis turns to the fundamental-and still open-question: What is the burden of proof the government must satisfy and the corresponding procedural protections it must provide, to justify detaining a citizen in military custody as an enemy combatant rather than in civilian custody with the usual constitutional rights? The analysis also considers a number of subsidiary questions related to the broader problem of burden of proof, including the circumstances under which application of the laws of war to alleged terrorists is justifiable, the scope of petitioner's access to counsel, and the role of concessions or undisputed facts. To date, no final judgment of any federal court has reached these issues in full on the merits. Yet, the question is one of paramount importance in the constitutional scheme and to which this Article gives an answer.

Only by considering these fundamental open questions unobstructed by the factual complexities of actual past and present litigation can the core constitutional controversies be seen and the appropriate balance of governmental power and individual rights be determined.

\section{WRIT OF HABEAS CORPUS: PROCEDURAL THRESHOLDS}

A petition for a writ of habeas corpus provides a procedure by which an individual in custody may seek judicial review of the lawfulness of that custody. The modern American law governing the filing of such petitions evolved from the common law Great Writ, which was used to challenge a citizen's summary detention by order of the Crown-a proceeding upon which considerable praise rightfully has been bestowed over the centuries. ${ }^{129}$

128. The writ also may be issued to terminate custody in violation of the laws or treaties of the United States. See 28 U.S.C. $\& 2241$ (c)(3) (2000). The assumptions previously stated exclude those two grounds by the terms of the hypothetical statute negating the application of other laws and treaties, with the exception of the laws of war.

129. See Hamdi, 124 S. Ct. at 2661-63 (Scalia, J., dissenting); Rasul v. Bush, 124 S. Ct. 2686, 2692-93 (2004); Hamdi, 316 F.3d at 465 (stating that habeas corpus review's "essential function of assuring that restraint accords with the rule of law, not the whim of 
So highly regarded was the necessity for the availability of the writ that the drafters of the Constitution specifically restricted the federal government's power to suspend it. ${ }^{130}$

A habeas corpus proceeding is a civil cause of action in which the petitioner, the prisoner, seeks release from the custody of the respondent, the warden of the facility where the prisoner is incarcerated. ${ }^{131}$ Despite its origin in executive detentions, contemporary habeas corpus law is concerned almost exclusively with challenges to incarceration pursuant to a judgment issued by a duly constituted court for conviction for a criminal offense. A federal offender may attack his imprisonment or his sentence in federal court under $\S 2255$ on the grounds that it was imposed in violation of the Constitution or federal law. ${ }^{132} \mathrm{~A}$ state prisoner, subject to numerous and highly technical procedural hurdles, similarly may petition in federal court under $\S 2254$ for a determination that his "custody is in violation of the Constitution, laws, or treaties of the United States." 133 The case law construing the federal statutory provisions providing these forms of relief is extensive. ${ }^{134}$

The detention of alleged terrorists as enemy combatants, however, marks a return to the very kind of incarceration for which the privilege of the writ of habeas corpus was designed: custody pursuant not to a judicial judgment, but rather executive fiat. As the Fourth Circuit noted in the Hamdi litigation:

While the scope of habeas review has expanded and contracted over the succeeding centuries, its essential function of assuring that restraint accords with the rule of law, not the whim of authority, remains unchanged. Hamdi's petition falls squarely within the Great Writ's purview, since he is an American citizen challenging his summary detention for reasons of state necessity. ${ }^{135}$

authority, remains unchanged"); id. at 464 (quoting 4 W. BLACKSTONE, COMMENTARIES ON THE LAWS OF ENGLAND 349-50 (Coolidge ed., 1889)).

130. See U.S. CoNST. art. I, $\S 9$, cl. 2.

131. See 28 U.S.C. $\$ \$ 2241$ (a), (d), 2242, 2254(a) (2000).

132. See 28 U.S.C. $\$ 2255$.

133. 28 U.S.C. $\$ 2254$ (a); see also id. $\$ \S 2244,2254$.

134. See, e.g., Miller-El v. Cockrell, 537 U.S. 322 (2003); Tyler v. Cain, 533 U.S. 656 (2001); Williams v. Taylor, 529 U.S. 420 (2000); Williams v. Taylor, 529 U.S. 362 (2000).

135. Hamdi v. Rumsfeld, 316 F.3d 450, 465 (4th Cir. 2003), vacated, 542 U.S. 507 (2004). 
In such circumstances, $\S 2241$ of the habeas corpus statutes applies; like the more commonly invoked statutes, that section permits a detainee to challenge his custody as "in violation of the Constitution or laws or treaties of the United States." 136 Therefore, if the President's detention of an alleged terrorist exceeds the constitutional powers of the federal government, a federal court may issue a writ of habeas corpus directing the President to release the individual from custody.

A § 2241 petition challenging the detention of an alleged terrorist designated by the President as an enemy combatant will be dismissed if it fails to satisfy certain jurisdictional prerequisites. First, the petition must be filed by an appropriate party against an appropriate respondent. These requirements usually are satisfied easily. Second, the petition must involve the custody of a prisoner to whom the privilege of the writ of habeas corpus under the Constitution applies - that is, the federal court must have subjectmatter jurisdiction over the controversy. It appears, however, that subjectmatter jurisdiction always should be present in petitions filed on behalf of United States citizens detained by the United States.

\section{A. Standing and Personal Jurisdiction: Petitioner and Respondent}

Only certain individuals may file a $\S 2241$ petition challenging a prisoner's detention. In the absence of a proper party, Article III courts lack the power to adjudicate the petition, just as an equivalent lack of standing would doom any other civil case. ${ }^{137}$ For $\S 2241$ cases, there are two permissible petitioners. ${ }^{138}$

First, of course, the prisoner may file the petition. In typical habeas cases under $\S 2255$ or $\S 2254$, the incarcerated criminal offender is the person who files the petition, often pro se. Although such persons face many practical obstacles in their pursuit of relief, they have access to the courts as well as to outside resources like family or friends to assist in their endeavors. Persons detained as enemy combatants, by contrast, may be held entirely incommunicado in military custody for extended periods of time. ${ }^{139}$ Such

136. 28 U.S.C. $\$ 2241$.

137. See Friends of the Earth, Inc. v. Laidlaw Envtl. Servs., 528 U.S. 167, 185 (2000); Lujan v. Defenders of Wildlife, 504 U.S. 555, 560 (1992).

138. "Application for a writ of habeas corpus shall be in writing signed and verified by the person for whose relief it is intended or by someone acting in his behalf." 28 U.S.C. $\S 2242$.

139. See supra text accompanying notes 118-19. 
conditions would make it impossible for the detainee to file personally a $\S$ 2241 petition to challenge his custody, and courts readily have recognized that dilemma. ${ }^{140}$

Second, a "next friend" may file a $\$ 2241$ petition on behalf of a detainee. To have standing to file as a next friend, the party claiming that status must explain why the detainee is unavailable to petition for his own release and must demonstrate a significant relationship to the detainee that ensures the party will be dedicated to the pursuit of the detainee's interests. ${ }^{141}$ Immediate family members, such as parents or siblings, are suitable next friends. ${ }^{142}$

Other persons are not proper next friends and cannot file a petition to challenge a prisoner's custody. To expand standing beyond the narrowly defined class of next friends would allow "intruders or uninvited meddlers, styling themselves next friends" to intervene in matters in which they hold no personal stake. ${ }^{143}$ For example, citizens who seek to vindicate "a generalized interest in constitutional governance"-but who lack any significant connections to the specific detainee-lack Article III standing. ${ }^{144}$ Similarly, while counsel who previously represented a detainee in connection with the investigation of his alleged terrorist ties prior to his designation as an enemy combatant possesses a significant relationship that justifies next friend status, the Federal Public Defender for the district in which the prisoner is being held lacks standing absent a preexisting professional

140. See Hamdi v. Rumsfeld, 294 F.3d 598, 603 (4th Cir. 2002), rev'd, 316 F.3d 450 (4th Cir. 2003), vacated, 542 U.S. 507 (2004); Padilla ex rel. Newman v. Bush, 233 F. Supp. 2d 564, 575-76 (S.D.N.Y. 2002), aff'd in part, rev'd in part sub nom. Padilla v. Rumsfeld, 352 F.3d 695 (2d Cir. 2003), rev'd, 542 U.S. 426 (2004).

141. See, e.g., Hamdi, 294 F.3d at 603-07; Padilla v. Rumsfeld, 352 F.3d 695, 702-04 (2d Cir. 2003), aff $g$ in relevant part Padilla, 233 F. Supp. $2 \mathrm{~d} 564$.

142. See Hamdi v. Rumsfeld, 296 F.3d 278, 280-81 (4th Cir. 2002), rev'd, 316 F.3d 450 (4th Cir. 2003), vacated, 542 U.S. 507 (2004); Hamdi, 294 F.3d at 600 n.1; Al Odah v. United States, 321 F.3d 1134, 1136-38 (D.C. Cir. 2003), rev'd by, Rasul v. Bush, 542 U.S. 466 (2004); Gherebi v. Bush, 262 F. Supp. 2d 1064, 1065 (C.D. Cal. 2003), rev'd on other grounds, 352 F.3d 1278 (9th Cir. 2003), vacated, 124 S. Ct. 2932 (2004).

143. Hamdi, 294 F.3d at 603 (internal quotation marks omitted) (quoting Whitmore v. Arkansas, 495 U.S. 149, 164 (1990)).

144. Id. (internal quotation marks omitted) (quoting Whitmore, 495 U.S. at 164); see also Coal. of Clergy v. Bush, 189 F. Supp. 2d 1036, 1039-46 (C.D. Cal. 2002), aff'd in relevant part, vacated in part sub nom. Coal. of Clergy, Lawyers, \& Professors v. Bush, 310 F.3d 1153 (9th Cir. 2002). 
relationship. ${ }^{145}$ The requirement of a significant prior relationship might be weakened if there was no party available to serve as a proper next friend on behalf of an incommunicado detainee, but as such facts have not yet arisen, the contours of a possible exception for such unusual circumstances are unresolved. ${ }^{146}$

The petition must be filed not only by a proper petitioner, but also against the proper respondent in the proper forum. In the usual case under $\S 2254$, the petition is filed in the federal district where the facility holding the incarcerated criminal offender is located, and the respondent is the warden of that facility; ${ }^{147}$ most courts have held that the same rule applies to $\S 2241$ petitions challenging the detention of aliens pending removal under the immigration laws. ${ }^{148}$ In the Hamdi case, the petition was filed in the district where the petitioner was detained at the time of filing. ${ }^{199}$ The petition in Padilla, however, was not filed in the Southern District of New York until after Padilla already had been taken into military custody and transferred to Charleston, South Carolina. ${ }^{150}$

The Supreme Court in Padilla resolved a split of authority that had developed in the courts of appeals regarding the proper respondent and

145. Compare Padilla, 233 F. Supp. 2d at 575-78 (prior relationship), with Hamdi, 294 F.3d at 603-07 (no prior relationship).

146. See Coal. of Clergy, 310 F.3d at 1165-68 (Berzon, J., concurring).

147. See Padilla, 233 F. Supp. $2 d$ at 578-80. Prior to the enactment of $\S 2255$, which provides for the motion to be filed in the district where the prisoner was sentenced, see 28 U.S.C. $\S 2255(2000)$, habeas petitions challenging federal sentences under $\S 2241$ were filed in the district where the prisoner was incarcerated, see United States v. Hayman, 342 U.S. 205, 212-19 (1952).

148. See, e.g., Robledo-Gonzalez v. Ashcroft, 342 F.3d 667, 673 (7th Cir. 2003); Vasquez v. Reno, 233 F.3d 688, 691 (1st Cir. 2000); In re Hansard, 123 F.3d 922, 925 \& n.2 (6th Cir. 1997). But see Ali v. Ashcroft, 346 F.3d 873, 887-88 (9th Cir. 2003); Yesil v. Reno, 175 F.3d 287, 287-88 (2d Cir. 1999); Henderson v. INS, 157 F.3d 106, 128 (2d Cir. 1998). In Padilla, the Supreme Court noted this split of authority. See Rumsfeld v. Padilla, $124 \mathrm{~S}$. Ct. 2711,2718 n.8 (2004).

149. Hamdi was detained at Norfolk naval base, which is located in the Eastern District of Virginia See Hamdi, 294 F.3d at 601. Accordingly, the lower courts in Hamdi did not address the forum issue in detail because both the commander of that base and Secretary of Defense Rumsfeld at the Pentagon, are located in the same district. See Colepaugh v. Looney, 235 F.2d 429, 430-33 (10th Cir. 1956) (petition filed in district where prisoner of war was detained); In re Territo, 156 F.2d 142, 144 (9th Cir. 1946) (same).

150. In Padilla, the next friend filed the petition at a previously scheduled hearing two days after Padilla was removed from the district into military custody. See Padilla, 233 F. Supp. 2d at 571-72; Padilla, 352 F.3d at 700. 
forum for a $\S 2241$ petition challenging an enemy combatant detention. The Second Circuit in Padilla and the Ninth Circuit in Gherebi reasoned that because enemy combatant detainees, unlike convicted criminals or deportable aliens detained pursuant to civilian law, are held at military installations at the direction of superiors in Washington, and accordingly the commander of a local military base was not the actual, de facto custodian of the custody the petitioner is challenging, the proper respondent was the Secretary of Defense, who exercises direct authority on behalf of the President over those detainees. ${ }^{151}$ Hence, the petition could be filed in the district where the next friend is located, rather than the district where the prisoner is actually detained, so long as personal jurisdiction over the Secretary is proper based on his ties to the district satisfying the relevant long-arm jurisdiction statute. ${ }^{152}$ On the other hand, the Seventh Circuit in $\mathrm{Al}$ Marri rejected this analysis and ruled that, notwithstanding that the prisoner was in military rather than civilian custody, the general rule applied and that the petition must be filed not against the Secretary of Defense, but rather against the immediate custodian: the commander of the military facility where the petitioner is detained. ${ }^{153}$ In a $5-4$ decision, the Supreme Court agreed with the Seventh Circuit and held that the general rule applied. ${ }^{154}$

The Court held that because Padilla was challenging a situation of "present physical confinement" by the government, the proper respondent was the warden of that facility and the proper forum was the district where the facility is located. ${ }^{155}$ The Court rejected the argument that the commander of a military base was not the appropriate respondent, emphasizing that a habeas petition is filed against the official who maintains the prisoner's custody, not the official who authorizes or imposes it. ${ }^{156}$ The Court also concluded that no exception to the general rule was appropriate ${ }^{157}$ and

151. See Padilla, 352 F.3d at 704-08, aff'g in relevant part 233 F. Supp. 2d 564; Gherebi, 352 F.3d at 1300-05.

152. See Padilla, 352 F.3d at 708-10, aff'g in relevant part, 233 F. Supp. 2d 564; Gherebi, 352 F.3d at 1300-05; cf. Al-Marri v. Bush, 274 F. Supp. 2d 1003, 1005-10 (C.D. III. 2003) (holding venue improper where neither prisoner nor next friend was located in district), aff'd on other grounds sub nom. Al-Marri v. Rumsfeld, 360 F.3d 707 (7th Cir. 2004).

153. See Al-Marri, 360 F.3d at 709-11.

154. See Rumsfeld v. Padilla, 124 S. Ct. 2711, 2722-25 (2004).

155. See id. at 2718-19, 2723-25.

156. See id. at 2720 n.13.

157. See id. at 2719-22, 2725-26; id. at 2728 (Kennedy, J., concurring). But see id. at 2732-35 (Stevens, J., dissenting). 
rejected the arguments of the dissenting Justices that given the nature of an enemy combatant detention by the military, the custody involved was sui generis. ${ }^{158}$ Significantly, the Court noted that had Padilla's petition been filed

The Court rejected several lower courts' arguments relying on prior cases involving challenges to custody other than present physical confinement. See Padilla, 352 F.3d 695, aff $g$ in relevant part, 233 F. Supp. 2d 564; Gherebi, 352 F.3d at 1300-01; see also Al-Marri, 360 F.3d at 711-12. In Braden v. 30th Judicial Circuit Court, the Court held that a prisoner confined in an Alabama prison could challenge a Kentucky detainer through a petition filed in federal court in Kentucky. See Braden, 410 U.S. 484, 495, 499-500 (1973). Although the prisoner was physically detained in Alabama, the custody challenged in the petition was the non-physical custody imposed by the Kentucky detainer-and thus the state court in which the indictment was pending was the proper respondent for the federal petition. See id. Similarly, in Strait v. Laird, the Court held that a reservist challenging orders to report for active duty could pursue his petition in California, where he was located. See Strait, 406 U.S. 341, 344-46 (1972). The Court held that the proper respondent was the officer ultimately responsible for issuing the challenged orders, who was located in Indiana, but nonetheless concluded that the petitioner should be treated as being in custody in California due to the Army's extensive handling of his matter there. See id. On the other hand, in Schlanger v. Seamans, the Court concluded that a petition alleging a breach of enlistment contract could not proceed in Arizona, where the petitioner was located. See Schlanger, 401 U.S. 487, 489-91 (1971). As in Strait, the proper respondent was the commanding officer in Georgia who imposed the custody by enforcing the challenged contract, but unlike Strait, that officer took no action in and had no ties to Arizona, so the appropriate district for the petition was Georgia. See id.; see also Strait, 406 U.S. at 344 (distinguishing Schlanger based on "total lack of formal contacts between Schlanger and the military" in Arizona).

The Court in Padilla correctly found each of these cases distinguishable because they involved the unusual situation where the prisoner, the custody, and the custodian were not all present in the same place, necessitating that the petition may be filed in the location of the custody rather than that of the prisoner or the custodian. For example, in Braden, the custody being challenged was not the physical custody of the Alabama incarceration, but rather the non-physical custody of the Kentucky detainer, so the petition was properly filed where the respondent was imposing that custody (Kentucky), even though the petitioner was physically elsewhere (Alabama). See 410 U.S. at 484-85. Similarly, the military orders challenged in Strait and Schlanger imposed custody where they were applied to the petitioner-California (not Indiana) in Strait, 406 U.S. at 341, and Georgia (not Arizona) in Schlanger, 401 U.S. at 487-88. Thus, these cases stand for the proposition that a petitioner may proceed in the district where the challenged custody exists, even if the petitioner is not present there (Kentucky in Braden or Georgia in Schlanger) or the respondent is not present there (California in Strait). In Rumsfeld, on the other hand, the facts fall squarely within the usual present physical confinement rule. See $124 \mathrm{~S}$. Ct. at 2720-21, 2723-24.

158. See Rumsfeld, $124 \mathrm{~S}$. Ct. at 2732-35 (Stevens, J., dissenting). Similar arguments were raised in the lower courts. Compare Gherebi, 352 F.3d at 1300-05 (treating enemy combatant detention as exceptional), and Padilla, $233 \mathrm{~F}$. Supp. $2 \mathrm{~d}$ at 583-87, aff'd in relevant part, 352 F.3d 695 (2d Cir. 2003), with Al-Marri, 360 F.3d at 709-12 (rejecting different 
prior to his removal from New York, that subsequent transfer of the prisoner to a facility in another district would not have affected the Southern District's continued exercise of jurisdiction over the case. ${ }^{159}$ The Court therefore ruled that because the petition in Padilla was not filed until after he had been removed from the Southern District of New York into military custody, jurisdiction over the petition was filed in the improper forum-and that the petition should have been filed in South Carolina against Commander Marr, not Secretary Rumsfeld. ${ }^{160}$

Although the Supreme Court in Padilla held that the present physical confinement rule applied to Padilla's case, a majority of the Court also declared that an exception to the rule would be appropriate if the government engaged in conduct designed to impede judicial review of the detention. Six Justices agreed that if the prisoner's location was secret or unknown, the petition could not be expected to comply with the district-of-confinement rule. ${ }^{161}$ Those Justices also agreed that governmental conduct designed to obtain a strategic advantage in litigation would not be allowed to thwart the filing of a petition or to compel the dismissal of one filed after the tactical behavior. ${ }^{162}$ On the facts of Padilla, however, only four Justices concluded that the timing of the President's designation of Padilla as an enemy combatant - after the conclusion of briefing and two days before a scheduled hearing on Padilla's pending motion to quash the material witness

treatment of enemy combatant detention). Despite the suggestion of the Seventh Circuit in $\mathrm{Al}$ Marri, see 360 F.3d at 710, a holding separating venue from actual physical custody would not necessarily authorize suit in any district in the country. Proper venue readily could be limited to the district either where the next friend resides (S.D.N.Y in Padilla), or where the respondent's office is located (E.D. Va. for the Secretary of Defense)-the rule applied in cases of military detentions of citizen overseas that occur outside any judicial district. See Rumsfeld, 124 S. Ct. at 2718 n.9 (citing cases), 2725 n.16 ("In such cases, we have allowed the petitioner to name as a respondent a supervisory official and file the petition in the district where the respondent resides.").

159. See Rumsfeld, 124 S. Ct. at 2721 (discussing Ex parte Endo, 323 U.S. 283 (1944)); see also Al-Marri, 360 F.3d at 712.

160. See Rumsfeld, 124 S. Ct. at 2722-25.

161. See id. at 2729 (Kennedy, J., concurring); id. at 2731-32 \& n.3 (Stevens, J., dissenting).

162. See id. at 2731-32 \& n.3 (Stevens, J. dissenting). Governmental conduct in a criminal case taken solely to gain a strategic or tactical advantage violates the Due Process Clause. See, e.g., United States v. Sherman, 150 F.3d 306, 313 (3d Cir. 1998); United States v. Ciampaglia, 628 F.2d 632, 639 (1 st Cir. 1980) (citing United States v. Marion, 404 U.S. 307, $324(1971)$ ). 
warrant ${ }^{163} \longrightarrow$ might qualify as such strategic conduct. ${ }^{164}$ Nevertheless, a majority of the Court recognized that the government's actions in handling the designation and the custody of alleged enemy combatants would have a bearing on the procedural requirements for a $\S 2241$ petition challenging that detention.

\section{B. Subject-Matter Jurisdiction}

In addition to the requirements of standing and personal jurisdiction, a petition challenging the detention of an alleged terrorist as an enemy combatant must fall within the subject-matter jurisdiction of the federal courts in $\S 2241$ cases. A writ of habeas corpus may only be issued to terminate custody in violation of the Constitution or federal laws, and the Constitution does not necessarily apply to every action taken by the government of the United States anywhere in the world. ${ }^{165}$ With respect to

163. See Padilla v. Rumsfeld, 352 F.3d 695, $699-702$ (2d Cir. 2003), rev'd, 542 U.S. 426 (2004); Padilla ex rel. Newman v. Bush, 233 F. Supp. 2d 564, 569-74 (S.D.N.Y. 2002), aff'd in part, rev'd in part sub nom. Padilla v. Rumsfeld, 352 F.3d 695 (2d Cir. 2003), rev'd, 542 U.S. 426 (2004).

164. See Rumsfeld, 124 S. Ct. at 2731-32 \& n.3 (Stevens, J., dissenting).

165. Like citizens, aliens present in the United States are protected by the constitutional provisions governing detentions. Accordingly, an alien detained in the United States as an enemy combatant possesses constitutional rights that may be vindicated through a $\$ 2241$ petition. In Quirin, for example, the Supreme Court considered petitions by six German soldiers arrested in New York and in Chicago contesting their designation as unlawful combatants subject to trial by military tribunal. See Ex parte Quirin, 317 U.S. 1, 2024 (1942). Similarly, in Yamashita, the Court heard a petition challenging the trial by military tribunal of the Japanese commander in the Philippines, a federal territory over which the United States had sovereignty at the time. See In re Yamashita, 327 U.S. 1, 5-9 (1946); see also Johnson v. Eisentrager, 339 U.S. 763, 779-80 (1950) (distinguishing Yamashita); Gherebi v. Bush, 352 F.3d 1278, 1285 (9th Cir. 2003) (same).

Foreign nationals abroad, however, do not possess the full scope of constitutional rights held by United States citizens or aliens present in the United States. For example, with respect to foreign nationals abroad, the Constitution is not given extraterritorial effect for purposes of seizures by United States agents or deprivations of liberty without due process. See Zadvydas v. Davis, 533 U.S. 678, 693 (2001) (stating that "[i]t is well established that certain constitutional protections available to persons inside the United States are unavailable to aliens outside of our geographic borders," including Fifth Amendment Due Process Clause); United States v. Verdugo-Urquidez, 494 U.S. 259, 273-75 (1990) (Fourth Amendment search); see also Al Odah v. United States, 321 F.3d, 1134, 1141 (D.C. Cir. 2003) ("The law of the circuit now is that a 'foreign entity without property or presence in this country has no constitutional rights, under the [D]ue [P] rocess [C]lause or otherwise." (quoting People's 
United States citizens, however, subject-matter jurisdiction for a $\S 2241$ petition alleging that the detention is unconstitutional or unlawful will exist.

Mojahedin Org. v. Dep't of State, 182 F.3d 17, 22 (D.C. Cir. 1999))), rev'd by Rasul v. Bush, 542 U.S. 466 (2004). Applying similar reasoning, in Johnson v. Eisentrager, the Supreme Court dismissed habeas petitions challenging the World War II-related detention of twentyone German nationals in a prison in Allied-occupied Germany. See Johnson, 339 U.S. 763, 765-67 (1950). The prisoners had been taken into custody in China and had been convicted by a U.S. military tribunal in Nanking for violating the laws of war by engaging in continuing military activities against the United States after the surrender of Germany, but not Japan. See $i d$. Unlike aliens present in the United States, the Court ruled, these aliens were not entitled to invoke habeas corpus proceedings to challenge the power of the military tribunals to try them or to otherwise contest the validity of their incarceration. See id. at 770-80; see also Zadvydas, 533 U.S. at 693; Verdugo-Uquidez, 494 U.S. at 269; Johnson, 339 U.S. at 777-78 ("We have pointed out that the privilege of litigation has been extended to aliens, whether friendly or enemy, only because permitting their presence in the country implied protection. No such basis can be invoked here ...."); Nash ex rel. Hashimoto v. MacArthur, 184 F.2d 606, 608 (D.C. Cir. 1950). But see Cole, Enemy Aliens, supra note 2, at 984 ("[The] principles [of Eisentrager] apply only in a time of declared war to citizens of the country with which we are at war.").

In Rasul v. Bush, 124 S. Ct. 2698 (2004), a 6-3 majority of the Supreme Court distinguished Eisentrager, id. at 2693-95, and held that subject-matter jurisdiction existed for $\$ 2241$ petitions filed on behalf of foreign nationals detained as enemy combatants at the Guantanamo Bay naval base, see id. at 2698. In particular, the Court emphasized that the base was under the de facto sovereignty of the United States, and that unlike Eisentrager, the petitioners in Rasul were neither nationals of countries with which the United States was at war, nor had they yet been given any process to contest their detention. See id. at 2693-98; id. at 2700 (Kennedy, J., concurring). In light of Rasul, it appears that the existence of subjectmatter jurisdiction for $\S 2241$ petitions challenging enemy combatant detentions of foreign nationals abroad will depend on the facts and circumstances of the case-the nature of the conflict, the process already provided, and the location of the detention. Compare Khalid $v$. Bush, 355 F. Supp. 2d 311, 323 (D.D.C. 2005) (holding that foreign nationals detained at Guantanamo lacked any constitutional or statutory rights), with In re Guantanamo Detainee Cases, 355 F. Supp. 2d 443, 464 (D.D.C. 2005) (holding that foreign nationals detained at Guantanamo possessed rights under Due Process Clause).

Finally, even if the Eisentrager-Rasul analysis precluded a $\$ 2241$ petition on behalf of a foreign national detained by the United States abroad, the United States remains subject to international law and to treaties that govern its conduct. Courts have noted that diplomatic measures may be taken by the foreign nationals' home countries to enforce the Geneva Conventions or other international obligations owed by the United States. See, e.g., Gherebi v. Bush, 262 F. Supp. 2d 1064, 1072 (C.D. Cal. 2003), rev'd, 352 F.3d 1278 (9th Cir. 2003), vacated 124 S. Ct. 2932 (2004); Rasul v. Bush, 215 F. Supp. 2d 55, 56-57 (D.D.C. 2002), rev'd, 542 U.S. 466 (2004); cf. Eisentrager, 339 U.S. at 789 n.14. As important as those obligations may be for purposes of the government's international reputation, however, they are not enforceable in federal court by foreign nationals not present in the United States. 
This is true whether the citizen is taken into custody within the United States, is taken into custody abroad and returned to the United States for detention, or is taken into custody abroad and detained abroad. In each of these circumstances, the Constitution applies to the actions of the federal government with respect to the citizen, and therefore claims of constitutional violations are cognizable under $\S 2241$. The petitioner may lose on the merits of the claim, of course, but the federal courts have power to hear them.

A citizen taken into custody inside the United States indisputably may challenge that detention as unconstitutional. After confirming standing and jurisdiction, for example, the courts considering the detention of José Padilla as an enemy combatant proceeded directly to the merits of the next friend's constitutional claims. ${ }^{166}$ Judge Wesley went so far as to point out that the writ of habeas corpus had not been suspended as provided in Article I, Section 9 of the Constitution, and yet the "government contends that Mr. Padilla can be held incommunicado for 18 months with no serious opportunity to put the government to its proof by an appropriate standard" that Padilla's detention is constitutional. ${ }^{167}$ Similarly, in Quirin, the Supreme Court heard the habeas claim of a citizen arrested in the United States who challenged his designation as an enemy combatant subject to trial by military tribunal for violations of the laws of war. ${ }^{168}$ And the famous Milligan case was a habeas petition challenging military detention and trial during the Civil War in violation of a controlling federal statute. ${ }^{169}$

166. See Padilla v. Rumsfeld, 352 F.3d 695, 710 (2d Cir. 2003), rev'd, 542 U.S. 426 (2004); Padilla ex rel. Newman v. Bush, 233 F. Supp. 2d 564, 587-96 (S.D.N.Y. 2002), aff'd in part, rev'd in part sub nom. Padilla v. Rumsfeld 352 F.3d 695 (2d Cir. 2003), rev'd, 542 U.S. $426(2004)$.

167. Padilla, 352 F.3d at 732 (Wesley, J., concurring in part and dissenting in part).

168. See Quirin, 317 U.S. at 18-25. Petitioner Haupt was a citizen; although the government alleged his allegiance to Nazi Germany constituted a renunciation of his citizenship, the Court did not reach that question because it held that Haupt was properly treated as an enemy combatant regardless. See id. at $20,37-38$. Notably, although the text of the President's order establishing the military tribunals seemed to suggest it sought to deny judicial review, the Court interpreted the order not to bar habeas review of the applicability of the order to a person or the President's power to issue it. See id. at 24-25. The Court similarly heard a habeas petition challenging the lawfulness of certain conditions imposed on citizens during the relocation of Japanese-Americans on the West Coast. See Ex parte Endo, 323 U.S. 283, 297-304 (1944).

169. The Court was unanimous that Milligan was entitled to release under the terms of the 1863 statute authorizing President Lincoln to suspend the writ of habeas corpus. See Ex parte Milligan, 71 U.S. (4 Wall.) 2, 107-08, 115-16, 130-31 (1866); id. at 134-35 (Chase, C.J., concurring). The Court divided over whether Congress had the power to authorize Milligan's 
A citizen of the United States seized abroad and subsequently detained in the United States also may challenge his detention as unconstitutional under $\S 2241 .{ }^{170}$ When the government sought dismissal of Yaser Hamdi's petition on the grounds that he was an enemy combatant captured on a battlefield in Afghanistan, the Fourth Circuit responded by ordering that the merits of the allegations be reached: "In dismissing, we ourselves would be summarily embracing a sweeping proposition-namely that, with no meaningful judicial review, any American citizen alleged to be an enemy combatant could be detained indefinitely without charges or counsel on the government's sayso." ${ }^{171}$ Although ultimately concluding that Hamdi's claim failed on the merits, the court dertermined that the fact that Hamdi was seized on a foreign battlefield only affected the degree of deference owed to the government's allegations, not Hamdi's right to challenge his detention in the United States. ${ }^{172}$

Subject-matter jurisdiction also exists for a citizen who is taken into custody abroad and remains detained there as an enemy combatant at the time the $\S 2241$ petition is filed. In Rasul v. Bush, opinions joined by all nine Justices strongly suggested that habeas jurisdiction always would exist for such a petition. ${ }^{173}$ Similarly, previous cases permitted habeas challenges to the detention of citizens abroad, such as petitions on behalf of persons

trial by military commission. See id. at 118-30; id. at 136-42 (Chase, C.J., concurring); see also Ex parte Merryman, 17 F. Cas. 144, 147-48, 150 (C.C.D. Md. 1861) (No. 9487). The Court later upheld the constitutionality of a statute depriving it of appellate jurisdiction in habeas cases, however. See Ex parte McCardle, 74 U.S. (7 Wall.) 506, 507-08, 514-15 (1868).

170. John Walker Lindh, a citizen seized in Afghanistan and ultimately detained in the United States, objected to his classification as an unlawful combatant, rather than a lawful combatant, in the motion to dismiss the criminal charges filed against him in district court. See United States v. Lindh, 212 F. Supp. 2d 541, 552-58 (E.D. Va. 2002).

171. Hamdi v. Rumsfeld, 296 F.3d 278, 283 (4th Cir. 2002), rev'd, 316 F.3d 450 (4th Cir. 2003), vacated, 542 U.S. 507 (2004).

172. See id. at 283-84; Hamdi v. Rumsfeld, 316 F.3d 450, 465, 475 (4th Cir. 2003), vacated, 542 U.S. 507 (2004); Hamdi v. Rumsfeld, 337 F.3d 335, 341 (4th Cir. 2003) (en banc) (opinions respecting denial of rehearing). The Fourth Circuit panel explained: "Hamdi's citizenship rightfully entitles him to file this petition to challenge his detention, but the fact that he is a citizen does not affect the legality of his detention as an enemy combatant." 316 F.3d at 475 .

173. See Rasul v. Bush, 124 S. Ct. 2686, 2696 (2004); id. at 2699 (Kennedy, J., concurring); id. at 2708 (Scalia, J., dissenting). Subsequently, a district court found that $\S$ 2241 jurisdiction exists when the United States citizen is detained abroad by a foreign government at the request of the United States. See Abu Ali v. Ashcroft, 350 F. Supp. 2d 28, 68-69 (D.D.C. 2004). 
incarcerated after conviction by a court martial, ${ }^{174}$ and in another series of cases the Court established that civilians residing or stationed abroad in affiliation with the United States Armed Forces cannot constitutionally be tried for criminal offenses by military courts-martial that do not provide full Fifth and Sixth Amendment rights. ${ }^{175}$ If such rights in the ordinary criminal justice process have extraterritorial application to citizens, then the government's power to detain a citizen in military custody as an enemy combatant likewise is subject to judicial review, even when the location of the custody is abroad. The fact that the prisoner was taken into custody and remained detained abroad might, as several opinions in the Hamdi case suggested, ${ }^{176}$ lead the court to extend more deference to the government's allegations on the merits. But it seems likely that $\S 2241$ provides subjectmatter jurisdiction to challenge the detention of a citizen of the United States by the government of the United States, regardless of where that detention takes place.

\section{WRIT OF HABEAS CORPUS: JUDICIAL REVIEW OF THE CONSTITUTIONALITY OF DETENTION}

The detention of alleged terrorists as enemy combatants is justifiably controversial. By detaining citizens pursuant to the laws of war, rather than civilian law, the government can deprive them of the constitutional rights to which they otherwise are entitled. Any such assertion of power by the government is rightfully viewed with a high degree of skepticism.

Yet, the fact that the government claims sweeping and dangerous authority does not itself answer the question of the proper scope of judicial review of that claim. After all, the federal courts are not the only check against abuse of power by Congress and the President-the political

174. See Rumsfeld v. Padilla, 124 S. Ct. 2711,2719 n.8, 2725 n.16 (2004) (citing United States ex rel. Toth v. Quarles, 350 U.S. 11 (1955); Burns v. Wilson, 346 U.S. 137 (1953)).

175. See Kinsella v. United States ex rel. Singleton, 361 U.S. 234, 235, 249 (1960); McElroy v. United States ex rel. Guagliardo, 361 U.S. 281, 283, 287 (1960); Grisham v. Hagan, 361 U.S. 278, 279-80 (1960); Reid v. Covert, 354 U.S. 1, 3-5 (1957); see also United States v. Verdugo-Urquidez, 494 U.S. 259, 269-70 (1990) (discussing Reid). Thus, "[c]ourtsmartial cannot be given jurisdiction, even abroad, over civilian dependents of military personnel or over civilian employees of the military forces." I LAURENCE H. TRIBE, AMERICAN CONSTITUTIONAL LAW § 3-5 at 301 ( 3 d ed. 2000) (footnotes omitted).

176. See $124 \mathrm{~S}$. Ct. at 2647-52 (plurality opinion); id. at 2680-82 (Thomas, J., dissenting); 337 F.3d at 345-57 (Traxler, J., concurring); id. at 357-68 (Luttig, J., dissenting). 
branches must stand for reelection and face the judgment of the voters. On the other hand, the courts are expected to play a greater role in protecting constitutional rights against encroachment by the other two branches precisely because political expediency-or the will of the majority-may pay insufficient attention to the Bill of Rights. And when the governmental powers at issue implicate foreign affairs and war-making, the role of the courts is usually more limited. Such questions of the separation of powers and the constitutional theory are as deeply contested as they are important.

The most direct implications of those issues for the proper role of judicial review of the detention of citizens as enemy combatants, however, relate to questions that this Article does not seek to address. The following analysis assumes that the federal government is exercising its maximum constitutional authority through a duly enacted statute that expressly authorizes the President to detain alleged terrorists as enemy combatants. ${ }^{177}$ Accordingly, absent a suspension of the writ and subject to the procedural thresholds, ${ }^{78}$ the federal courts have power to hear petitions for the writ of habeas corpus challenging the constitutionality of such detentions.

With all other objections of constitutional law set aside, a single fundamental question remains: the mandates of the Due Process Clause concerning the nature and the scope of the process that is due before the government may detain a citizen in military custody as an enemy combatant, rather than in civilian custody with the usual constitutional rights. Citizens presumptively possess the full range of constitutional rights, and seeking to detain a citizen as an enemy combatant is an extraordinary exercise of governmental power that deprives the individual of those rights. Accordingly, due process requires that the government rebut the presumption of constitutional rights only with a significant showing under rigorous procedures.

This Part analyzes this fundamental question and provides the answer the courts so far have avoided. The analysis begins with consideration of the circumstances under which the application of the laws of war to alleged terrorists is justifiable as grounds for the detention of a citizen as an enemy combatant. This Part then examines the Due Process Clause inquiry, including the deprivations of liberty at stake, the burden of proof the government must satisfy, the corresponding procedural protections that must be provided, and the petitioner's right of access to counsel.

177. See supra Part II.D.

178. See supra Part III. 


\section{A. The Laws of War and of Alleged Terrorists}

The Due Process Clause analysis must begin by defining an "enemy combatant" who may be detained in military custody under the laws of war, rather than in civilian custody with the usual constitutional rights. The determination of what process is due to justify the deprivations of liberty imposed by an enemy combatant detention cannot be made without first determining what facts must be proven to establish that the citizen being detained is in fact an enemy combatant. Once the category of enemy combatants is defined, the inquiry can proceed to the nature and the scope of the process that is due when the government seeks to detain a citizen under that authority.

Detention of citizens in military custody under the laws of war is an extraordinary governmental power that removes those citizens from the protections of the constitutional rights applicable under civilian authority. The power to detain citizens as enemy combatants derive from the laws of war: those who engage in acts of war against the United States-even if they are citizens-may be treated in kind, by applying the laws of war to their conduct. ${ }^{179}$ Enemy combatant detentions, thus, are authorized only in the cases of those citizens who have become war enemies of the United States; they are not authorized for ordinary criminals who harm the government or the nation or for persons of questionable allegiance or loyalty who have not taken actions that rise to violations of the laws of war. ${ }^{180}$ Accordingly, due

179. See supra Part II.B.; see also, e.g., AM. BAR ASS'N, TASK FORCE ON TREATMENT of ENEMY COMBatants ET Al., Report to the House of Delegates (Feb. 10, 2003); News Release No. 497-02, United States Department of Defense, DOD Responds to ABA Enemy Combatant Report (Oct. 2, 2002), available at http://www.defenselink.mil/news/Oct2002/ b10022002_bt497-02.html (responding to AM. BAR ASs'N, TASK FORCE ON TREATMENT OF ENEMY COMBATANTS, PRELIMINARY REPORT (Aug. 8, 2002)); Kacprowski, supra note 58, at 652; Schaffer, supra note 58, at 1468.

180. See Spencer J. Crona \& Neal A. Richardson, Justice for War Criminals of Invisible Armies: A New Legal and Military Approach to Terrorism, 21 OKLA. CITY U. L. REv. 349, 369-70 (1996); Noah Feldman, Choices of Law, Choices of War, 25 HARV. J.L. \& PUB. POL'Y 457, 464-65 (2002); Fletcher, supra note 83, at 641-45; Iraola, supra note 58, at 586-87; Katyal \& Tribe, supra note 83, at 1261; McCormack, supra note 83, at 47-48; Manooher Mofidi \& Amy E. Eckert, "Unlawful Combatants" or "Prisoners of War": The Law and Politics of Labels, 36 CORNELL. INT'L L.J. 59, 73-74 (2003); Jordan J. Paust, War and Enemy Status After 9/11: Attacks on the Laws of War, 28 YALE J. INT'L L. 325, 332 (2003) [hereinafter War and Enemy Status]; Ingrid Brunk Wuerth, The President's Power to Detain Enemy Combatants: Modern Lessons from Mr. Madison's Forgotten War, 98 Nw. U. L. REv. 1567, 1573-78 (2004); John C. Yoo \& James C. Ho, The Status of Terrorists, 44 VA. J. INT'L 
process requires that the category of persons subject to such military detention be narrowly circumscribed; otherwise the exceptional nature of the power is not maintained. ${ }^{181}$

In Hamdi, the Supreme Court briefly addressed the definition of enemy combatants in the context of a citizen seized in Afghanistan while allegedly taking up arms with the Taliban and against United States military forces there. ${ }^{182}$ The plurality opinion noted that the definition of enemy combatant status was unclear, but found that a finding of such status required, at a minimum, proof that the individual was a member of a hostile armed force who engaged in acts of armed conflict. ${ }^{183}$ The plurality opinion then rejected the government's claim that Hamdi's petition conceded those facts; ${ }^{184}$ it held that the government's proof was inadequate and remanded the case for further proceedings to provide Hamdi with due process. ${ }^{185}$

While the general definition of enemy combatants applied by the Hamdi plurality was sufficient for purposes of that case, a more detailed definitional analysis is necessary to determine how the laws of war apply to alleged terrorists. Such analysis explains what the government must prove to justify

L. 207, 213-15 (2003); Note, Responding to Terrorism: Crime, Punishment, and War, 115 HARV. L. REV. 1217, 1228-29 (2002).

For example, although the bombing of the Oklahoma City federal building in 1995 has been characterized as an act of domestic terrorism, the individuals responsible for the attack were prosecuted in civilian court. See generally United States v. Fortier, 242 F.3d 1224 (10th Cir. 2001), superceded by statute, 18 U.S.C. $\$ 3742(q)(2)(2000)$, as recognized in United States v. Bolden, 368 F.3d 1032 (8th Cir. 2004); United States v. Fortier, 180 F.3d 1217 (10th Cir. 1999); United States v. Nichols, 169 F.3d 1255 (10th Cir. 1999), superceded by statute, 18 U.S.C. $\$ 3742(q)(2)(2000)$, as recognized in United States v. Bolden, 368 F.3d 1032 (8th Cir. 2004); United States v. McVeigh, 153 F.3d 1166 (10th Cir. 1998).

181. This argument is analogous to the usual requirement that when the government deprives a person of constitutional rights, that deprivation must be narrowly tailored to impose as minimal of a deprivation as possible. See, e.g., Eugene Volokh, Freedom of Speech, Permissible Tailoring and Transcending Strict Scrutiny, 144 U. PA. L. REV. 2417, 2419-20 (1996) (describing four elements of narrow tailoring in First Amendment cases); see also, e.g., Grutter v. Bollinger, $123 \mathrm{~S}$. Ct. 2325, 2344-47 (2003) (narrow tailoring of racial classifications in higher education); Hill v. Colorado, 530 U.S. 703, 739-40 (2000) (narrow tailoring of restrictions on constitutional right to abortion); Adarand Constructors, Inc. v. Pena, 515 U.S. 200, 235-38 (1995) (narrow tailoring for racial classifications in employment).

182. See Hamdi v. Rumsfeld, 124 S. Ct. 2633, 2635-39 (2004) (plurality opinion).

183. See id. at 2639. The Court noted that the definition could be clarified in further detail in the lower courts as challenges to enemy combatant detentions arise. See id. at 2642 n.1.

184. See id. at 2644-45.

185. See id. at 2645-52. 
detaining a citizen as an enemy combatant under the laws of war when the seizure is made not on a battlefield, but in the course of antiterrorism efforts.

The definitional analysis first involves determining whether the laws of war may be applied to terrorist groups at all. ${ }^{186}$ The scholarly commentary generally is in agreement that the laws of war apply to terrorists: Nongovernmental organizations that carry out acts of terrorism against the United States are belligerent armed forces engaged in armed conflict within the terms of the laws of war. ${ }^{187}$ For example, had the September 11 th attacks been executed by agents of a foreign nation, the attacks clearly would have been acts of war that constituted unlawful belligerency against the United States. ${ }^{188}$ Given that Al Qaeda is a highly structured multi-national terrorist

186. In the only case involving an enemy combatant detained as an alleged terrorist to reach the merits of the question, the district court held that a citizen seized in the United States may be detained as an enemy combatant; that ruling was vacated on other grounds by subsequent appellate decisions. See Padilla v. Rumsfeld, 233 F. Supp. 2d 564, 588-96 (S.D.N.Y. 2002), aff'd in part, rev'd in part, 352 F.3d 695 (2d Cir. 2003), rev'd, 542 U.S. 426 (2004). Other cases involved alleged enemy combatants seized during military actions in Afghanistan and, accordingly, did not address the application of the laws of war to terrorists. See Hamdi v. Rumsfeld, 124 S. Ct. 2633 (2004); United States v. Lindh, 212 F. Supp. 2d 541 (E.D. Va. 2002).

187. See, e.g., George H. Aldrich, The Taliban. Al Qaeda, \& the Determination of Illegal Combatants, 96 AM. J. INT'L L. 891, 893-94 (2002); Araujo, supra note 83, at 129; Bradley \& Goldsmith, supra note 83, at 251; Rosa Ehrenreich Brooks, War Everywhere: Rights, National Security Law, and the Law of Armed Conflict in the Age of Terror, $153 \mathrm{U}$. PA. L. REV. 675, 679-81 (2004); Feldman, supra note 180, at 464-65; Derek Jinks, September 11 and the Laws of War, 28 YALE. J. INT'L L. 1, $45-47$ (2003) [hereinafter Jinks, Laws of War]; Derek Jinks, The Declining Significance of POW Status, 45 HARv. INT'L L.J. 367, 40304 (2004); Wedgwood, supra note 83, at 335-36; Yoo \& Ho, supra note 180, at 209-18. But see, e.g., Evans, supra note 49, at 1851-54; Fitzpatrick, supra note 83, at 346-47; Joan Fitzpatrick, Sovereignty, Territoriality, and the Rule of Law, 25 HASTINGS INT'L \& COMP. L. REV. 303, 340 (2002); Michael H. Hoffman, Terrorists Are Unlawful Belligerents, Not Unlawful Combatants: A Distinction with Implications for the Future of International Humanitarian Law, 34 CASE W. RES. J. INT'L L. 227, $227-29$ (2002); Orentlicher \& Goldman, supra note 83, at 658-59; Paust, Detention, supra note 83, at 14; Jordan J. Paust, Post-9/11 Overreaction and Fallacies Regarding War and Defense, Guantanamo, the Status of Persons, Treatment, Judicial Review of Detention, and Due Process of Military Commissions, 79 NOTRE DAME L. REV. 1335, 1352 (2004).

188. See, e.g., Alexander, supra note 83 , at 890; Bradley \& Goldsmith, supra note 83 , at 251 (discussing Quirin); Crona \& Richardson, supra note 180, at 365-66; Feldman, supra note 180, at 469-70; Hoffman, supra note 187, at 229; Jinks, Laws of War, supra note 187, at 1-2; Wedgwood, supra note 49, at 335; Yoo \& Ho, supra note 180, at 209-13; John Yoo, Transferring Terrorists, 79 NOTRE DAME L. REV. 1183,1195 (2004). 
organization, it is appropriate to apply the laws of war to its actions. ${ }^{189}$ Thus, it is consistent with due process to conclude that Al Qaeda is an armed force engaged in armed conflict against the United States.

The definitional inquiry next must determine what types of connections with a terrorist group are necessary to permit the conclusion that an individual citizen is an enemy combatant. In light of the extraordinary nature of the enemy combatant designation, due process requires that a citizen not be deemed a belligerent engaged in armed conflict against the United States unless the citizen's actions and intentions are those of a soldier committing violations of the laws of war, rather than ordinary violent activity or disloyal conduct punishable criminally under civilian authority. Absent such actions and intentions, a citizen is not engaged in armed conflict under the laws of war.

Only citizens who are active present members of a terrorist group and who have specific intent to carry out imminent acts of terrorism against the United States may be detained as enemy combatants under the laws of war. Short of these criteria-active present membership and intention of imminent terrorism acts-a citizen cannot be considered an enemy belligerent against the United States consistent with due process.

A citizen who is actively and presently participating in a terrorist organization is a member of an armed force that is, as an organization, engaged in armed conflict against the United States. By possessing specific intent to carry out an imminent terrorist act, the citizen is, as an individual, a belligerent engaged in conduct that violates the laws of war. ${ }^{190}$ It is this combination of membership and conduct that permits the citizen to be removed from civilian authority and detained instead under military authority.

Ties to a terrorist organization alone are not sufficient to deem a citizen an enemy combatant because the citizen must be a belligerent to be subject to the laws of war. Past associations with a terrorist group, for example, would not make a citizen a present threat of committing acts of armed

189. See Lawrence Azubuike, Status of Taliban and Al Qaeda Soldiers: Another Viewpoint, 19 CONN J. INT'L L. 127, 134-38 (2003); Feldman, supra note 180, at 469-71; Jinks, Laws of War, supra note 187, at 9, 33-34; Maddox, supra note 83, at 446-51; Mofidi \& Eckert, supra note 180, at 73-74; Wedgwood, supra note 49, at 335; Yoo \& Ho, supra note 180, at 225; Yoo, supra note 188, at 1193-98. But see Paust, War and Enemy Status, supra note 180 , at $326-27$.

190. Of course, if the citizen is seized after actually carrying out or attempting to carry out a terrorist attack, that intention also is sufficient. 
conflict. Similarly, the fact that a citizen swore allegiance to Osama bin Laden or another terrorist leader would not make the individual a belligerent under the laws of war. ${ }^{191}$ Even a citizen who provides support to terrorists, or who facilitates obstruction of justice on their behalf, is not necessarily himself a belligerent engaged in armed conflict against the United States under the laws of war. ${ }^{192}$ Each of these forms of conduct and others, of course, may be prosecuted criminally in civilian courts for any number of offenses. ${ }^{193}$ But this conduct, standing alone, does not rise to the level of a violation of the laws of war.

Likewise, a specific intention to carry out an imminent terrorist attack is not alone sufficient to deem a citizen an enemy combatant because a substantial connection to an armed force engaged in armed conflict against the United States is also necessary before the laws of war apply. For example, the Oklahoma City federal building bombing was an act of terrorism, but it was a domestic act without any connection to an armed conflict governed by the laws of war. Acts of terrorism violate the laws of war only if they are conducted pursuant to an armed conflict against the United States, such as the one waged by Al Qaeda.

The requirements of active present membership in a terrorist group and intention to carry out an imminent terrorist act are further illuminated by a comparison of terrorism to the underlying principles of the laws of war. The Geneva Convention and its definitions of lawful and unlawful enemy combatants derive from a model of international warfare between nationstates with regular and irregular armed forces engaged in fighting on

191. Zacarias Moussaoui is being prosecuted in civilian court notwithstanding his apparent admission that he is a member of Al Qaeda. See United States v. Moussaoui, 365 F.3d 292, 331 (4th Cir. 2004) (Gregory, J., concurring in part and dissenting in part) (noting that Moussaoui admits membership in Al Qaeda and intent to commit terrorist acts against the United States, but disclaims participation in the September 11th attacks which forms the basis of the government's death penalty allegations against him).

192. Persons who affirmatively become complicit in acts of armed conflict would qualify as belligerents. See Military Order, supra note 80, at 57,834 ("engaged in, aided or abetted, or conspired to commit, acts of international terrorism"); Military Commission Instruction No. 2, supra note 82, at Part 6.C (providing liability for military tribunal offenses on grounds of, inter alia, aiding and abetting, accessory after the fact, and conspiracy).

193. See, e.g, 18 U.S.C. $\S 2332 b(b)(2)(2000)$ (accessory after the fact liability for acts of terrorism); id. $\S 2339$ (a) (harboring or concealing terrorists); id. $\S 2339 \mathrm{~A}(\mathrm{a})$ (providing material support to terrorists); id. $\S 2339 \mathrm{~B}(\mathrm{a})(1)$ (providing material support to foreign terrorist organization); see also, e.g., id. $\$ 1001$ (a) (false statements); id. $\$ 1510$ (obstruction of justice); $i d$. $\$ \S 1621-23$ (perjury and false declarations). 
conventional battlefields of relatively defined parameters. ${ }^{194}$ Person seized on such conventional battlefields, such as during recent United States military actions against the Taliban regime in Afghanistan or Saddam Hussein's government in Iraq, fall within this usual framework. ${ }^{195}$ As the Hamdi Court noted, presence in a foreign zone of combat is far from sufficient to deem a person an enemy combatant ${ }^{196}$ - but neither can the nature of the location be ignored. The government's evidence that a person was seized on a battlefield, while not conclusive, certainly has weight in establishing the government's claim that the person is in fact an enemy belligerent engaged in armed conflict against the United States.

The same reasoning explains why the application of the laws of war to alleged terrorists must be narrowly restricted by the membership and the conduct requirements. Unlike the model of conventional armed conflict underlying the laws of war, terrorist activities do not take place primarily on geographically limited battlefields. Instead, terrorist attacks may take place anywhere at any time and by their very nature are not designed to strike military, but rather civilian targets. While acts of terrorism constitute acts of armed conflict in violation of the laws of war, that cannot mean that the entirety of the United States is now a "battlefield" simply because a terrorist attack could occur somewhere at some time. Such a determination would stretch the laws of war far beyond their ordinary meaning and would enable

194. See Joan Fitzpatrick, Rendition and Transfer in the War Against Terrorism: Guantánamo and Beyond, 25 LoY. L.A. INT'L \& COMP. L. REV. 457, 462 (2003); Herman, supra note 83, at 76-82; Hoffman, supra note 187, at 227-28; Mofidi \& Eckert, supra note 180, at 61-72; K. Elizabeth Dahlstrom, Note, The Executive Policy Toward Detention and Trial of Foreign Citizens at Guantanamo Bay, 21 BERKELEY J. INT'L L. 662, 664-69 (2003).

195. See Hamdi v. Rumsfeld, 124 S. Ct. 2633, 2635-37 (2004); Rasul v. Bush, 124 S. Ct. 2686, 2690 (2004); United States v. Lindh, 212 F. Supp. 2d 541, 552 (E.D. Va. 2002); see also Mike Allen \& Susan Schmidt, Memo on Interrogation Tactics Is Disavowed; Justice Document Had Said Torture May Be Defensible, WASH. POST, June 23, 2004, at A1 (discussing legal issues surrounding reports of Iraqi prisoner abuse by United States soldiers); see also Aldrich, supra note 187, at 893; Azubuike, supra note 189, at 141-54; Belknap, supra note 83, at 447-48; Joshua S. Clover, "Remember, We're the Good Guys": The Classification and Trial of the Guantanamo Bay Detainees, 45 S. TEX. L. REv. 351, $355-69$ (2004); Matheson, supra note 83, at 355; Mofidi \& Eckert, supra note 180, at 86-87; Paust, Detention, supra note 187, at 327-31; Yoo \& Ho, supra note 180, at 218-19; John W. Broomes, Note, Maintaining Honor in Troubled Times: Defining the Rights of Terrorism Suspects Detained in Cuba, 42 WASHBURN L.J. 107, 122-28 (2002); Dahlstrom, supra note 194, at 675-76. See generally McCormack, supra note 83 (speculating on whether military commissions can be assembled for Al Qaeda members).

196. See infra notes $238-42$ and accompanying text. 
the government to invoke military authority in circumstances that look nothing like the "armed conflict" governed by those principles. When the government seizes a citizen in ordinary civilian conditions, due process does not permit that person to be detained as an enemy combatant under the laws of war without proof that the citizen is at that time and place a belligerent engaged in armed conflict against the United States.

The Supreme Court's holding in Quirin supports the conclusion that the laws of war cannot be applied to civilian locations in the United States absent proof of present belligerency. The German soldiers, including one United States citizen, landed on beaches in Florida and in New York, discarded their uniforms, entered the civilian population, and subsequently were captured by the FBI in New York and in Chicago ${ }^{197}$ The Court did not find that the mere presence of German soldiers in the United States constituted unlawful belligerency. ${ }^{198}$ Instead, the Court emphasized that the violation of the laws of war was presence in the civilian population, without uniforms identifying them as soldiers, combined with "the purpose of committing hostile acts" of sabotage against military targets. ${ }^{199}$ The Court further explained that the violation of the laws of war "was complete when with that purpose they entered-or, having so entered, they remained upon-our territory in time of war without uniform." ${ }^{200}$ Although commission or attempted commission of sabotage was not required for enemy combatant status, the intent to commit hostile acts behind civilian lines was necessary to make their conduct a violation of the laws of war, rather than a civilian offense. ${ }^{201}$ In the absence of a violation of the laws of war, moreover, the Milligan rule would control and would prohibit subjecting a non-belligerent to military detention or trial because the civilian courts are open and functioning. ${ }^{202}$

Thus, when the government seeks to detain a citizen as an enemy combatant, the Due Process Clause requires that the government prove that the person is in fact an enemy belligerent presently engaged in armed conflict against the United States. When the citizen is seized on a foreign battlefield fighting with an enemy armed force, those circumstances provide

197. Ex parte Quirin, 317 U.S. 1, 20-24 (1942).

198. See id. at 36-45.

199. Id. at 36 (ellipsis omitted). The Court reached the sufficiency of only one of the four charges of violations of the laws of war. See id. at 23, 46-48.

200. Id. at 38 (emphasis added).

201. See id. ("Nor are petitioners any the less belligerents if, as they argue, they have not actually committed or attempted to commit any act of depredation ....").

202. See supra notes 58-69 and accompanying text. 
the belligerency under the laws of war. When the citizen is seized on allegations that the person is a terrorist, however, such belligerency must be proven by demonstrating that the citizen is an active present member of a terrorist group (equivalent to membership in the German Army in Quirin) and that the citizen has specific intent to carry out an imminent terrorist attack (equivalent to the intent to commit sabotage in Quirin). Without the requirement of an imminent attack, the equivalency to conventional military belligerency is lost. Just as the Quirin Court treated enemy soldiers as having an intent to execute their orders to commit sabotage, so too the government must prove that the alleged terrorist had an intent to carry out a terrorist attack within a short period of time. Mere presence behind "enemy lines" is insufficient; the intent to commit belligerent acts is necessary. For example, members of alleged terrorist "sleeper cells" who are found in the United States, but have no present intention to commit any terrorist attacks may not be detained as enemy combatants because their conduct has not yet risen to the level of a violation of the laws of war. Only when an alleged terrorist has such a present intention to engage in acts of armed conflict against the United States is the citizen a belligerent who may be detained under military rather than civilian authority.

\section{B. Due Process and United States Citizens}

The Constitution guarantees to United States citizens a wide range of rights that the federal government may infringe only upon the most compelling grounds. ${ }^{203}$ Included among these are the constitutional provisions and rights regarding the procedures that must be followed to deprive a citizen of liberty for punitive or non-punitive reasons. ${ }^{204}$ Accordingly, the issue of enemy combatant detention must be analyzed under the Due Process Clause to determine how much process is due before a citizen may be denied liberty-not only physical liberty, but also constitutional rights.

The presumption that citizens retain these rights when the government seeks to detain them, even on serious allegations like espionage or terrorism

203. See Grutter v. Bollinger, 123 S. Ct. 2325, $2237-38$ (2003) (discussing strict scrutiny under Equal Protection Clause); Turner Broad. Sys. v. F.C.C., 512 U.S. 622, 641-43 (1994) (discussing strict scrutiny under First Amendment); Perry Educ. Ass'n v. Perry Local Educators' Ass'n, 460 U.S. 37, 54 (1983) (discussing application of strict scrutiny to "fundamental rights"); San Antonio Sch. Dist. v. Rodriguez, 411 U.S. 1, 17 (1973) (same).

204. See generally supra Part II.A. 
or treason, ${ }^{205}$ is a very strong one. The power to detain citizens in military custody as enemy combatants is an extraordinary assertion of authority precisely because it deprives those citizens of the legal liberties to which they otherwise would be fully entitled. Thus, the process due should be considerable.

Yet, the possession of constitutional rights is not an irrebuttable presumption. As the Supreme Court recognized in Ex parte Quirin, when a citizen joins an enemy armed force and engages in acts of war against the United States, that citizen rightfully is treated as an enemy combatant under the laws of war. ${ }^{206}$ For example, an American citizen captured during World War II while fighting for the Italian Army in Italy was without question an enemy soldier-not a civilian entitled to be tried in a criminal court. ${ }^{207}$ Similarly, were José Padilla or Yaser Hamdi members of the Iraqi Army and taken prisoner during the recent military action in that country, their status as prisoners of war would not be open to question. That the government chose to pursue civilian charges against John Walker Lindh, who fought with the Taliban militias in Afghanistan, does not change the fact that he was an unlawful enemy combatant and therefore not constitutionally entitled to a civilian hearing. ${ }^{208}$

In light of this strong presumption in favor of the retention of constitutional rights and the extraordinary nature of the governmental power invoked, the adjudication of a habeas corpus petition challenging an enemy combatant detention involves a due process analysis more similar to the historical Great Writ than to contemporary habeas attacks on criminal incarceration. In the typical modern case the petitioner bears the burden of

205. For example, John Walker Lindh was charged in civilian court; he ultimately pled guilty to two counts (aiding the Taliban and a weapons offense) and received a sentence of twenty years' imprisonment. See Tom Jackman, In Deal, Lindh Pleads Guilty to Aiding Taliban, WASH. POST, July 16, 2002, at A1. Similarly, Robert Philip Hanssen was permitted to plead guilty to thirteen counts of espionage and a sentence of life imprisonment to avoid the death penalty. See David A. Vise, From Russia With Love; FBI Agent Robert Hanssen Was a Frustrated Loner Isolated From Co-workers, Family and Friends. Finally He Found Someone to Appreciate His Mind and Talents: The Nice Folks From the KGB, WASH. PosT, Jan. 6, 2002, at W18. Neither Lindh nor Hanssen was ever charged with treason. Treason trials are held in Article III courts under requirements of proof expressly delineated in the Constitution. See U.S. CONST. art. III, § 3.

206. See 317 U.S. at 15-16.

207. See In re Territo, 156 F.2d 142, 142-46 (9th Cir. 1946).

208. See United States v. Lindh, 212 F. Supp. 2d 541, 552-58 (E.D. Va. 2002) (discussing Lindh's status as unlawful enemy combatant). 
proving the constitutional violation that invalidates his conviction. Because the petition is a collateral attack on a final conviction, a habeas court properly regards the previous proceedings as valid and legitimate, unless the petitioner can prove otherwise. ${ }^{209}$ In a challenge to an enemy combatant detention, by contrast, there is no previous judicial judgment authorizing the detention, but rather confinement by executive decreo-a kind of confinement that is ordinarily unconstitutional. ${ }^{210}$ For example, a petitioner who established that his incarceration in a state prison was maintained pursuant to a declaration by the state's governor ordering him confined, rather than pursuant to any judicial judgment of criminal conviction or civil confinement, would be entitled to federal habeas relief. Similarly, absent the power to detain citizens under the laws of war, if a $\S 2241$ petitioner established that he was confined indefinitely in military custody pursuant to a presidential order, rather than a judicial judgment, then he would be entitled to immediate release from custody. Only the extraordinary power to detain enemy combatants under the laws of war provides an exception to this principle.

The executive detention of alleged terrorists as enemy combatants is precisely the exceptional situation contemplated by the provisions of the federal habeas statutes that, unlike the provisions applicable to challenges to criminal convictions, ${ }^{211}$ resemble the traditional Great Writ. In a $\$ 2241$ proceeding, the court "entertaining an application for a writ of habeas corpus shall forthwith award the writ or issue an order directing the respondent to show cause why the writ should not be granted, unless it appears from the application that the applicant or person detained is not entitled thereto," and the respondent "shall make a return certifying the true cause of the detention." 212 The statutes therefore contemplate the procedure that due process requires in this context: it is not the petitioner's burden to prove that he is not a terrorist subject to the laws of war; it is the respondent's burden to prove that he is. Due process requires that the government justify in each

209. See, e.g., Romine v. Head, 253 F.3d 1349, 1357 (11th Cir. 2001) (burden is on prisoner to prove invalidity of conviction); Lockett v. Anderson, 230 F.3d 695, 707 (5th Cir. 2000) (same); see also 28 U.S.C. $\$ 2254$ (d) (2000) (presumption of regularity in state court legal rulings); id. $\$ 2254$ (e) (presumption of regularity in state court factual records); id. $\S 2254$ (b)-(c) (requirement of exhaustion of state appeals of collateral attacks on conviction).

210. See Rasul v. Bush, 124 S. Ct. 2686, 2698 n.15 (2004) ("Petitioner's allegations ... unquestionably describe 'custody in violation of the Constitution or laws or treaties of the United States."' (quoting 28 U.S.C. § 2241 (c)(3))).

211. See 28 U.S.C. $\$ \S 2241$ (d), 2244(a), 2244(c)-(d), 2249, 2254, 2255.

212. Id. § 2243 (emphasis added). 
particular case the extraordinary nature of the enemy combatant detention at issue, and the habeas statutes authorize such a shifting of the burden of proof in $\S 2241$ cases of this nature.

Thus, the core due process issue is whether the government justified its decision to detain specific individuals as enemy combatants on the particular facts of their seizures into government custody. That is, the sole question is whether the government provided sufficiently persuasive proof that the prisoner it labeled as an enemy combatant, in fact, is one. In addition to establishing the applicability of the laws of war in the first instance, the government must prove that the individual detained as an enemy combatant committed the acts alleged and therefore can be held in military custody and denied the constitutional rights that otherwise would apply. After evaluating the deprivations of liberty involved in an enemy combatant detention, the analysis of what process is due such citizens involves two principal issues: the government's burden of proof and the corresponding procedural protections with which the government must comply in attempting to meet that burden.

\section{Deprivations of Liberty in Enemy Combatant Detentions}

The consequences of detaining a United States citizen as an enemy combatant involve substantial deprivations of liberty. It is these dramatic consequences that compel the conclusion that the Due Process Clause mandates significant procedural protections before the government can justify imposing such deprivations on the petitioner.

First, an enemy combatant detention obviously involves a deprivation of physical liberty when the prisoner is incarcerated indefinitely. Yet, this deprivation of physical liberty is not one recognized in the framework of civilian law; rather, it is an extraordinary power that can be invoked only in a narrow range of wartime circumstances. Although the requirements of the Due Process Clause for enemy combatant detentions have not been established by the courts, the range of existing doctrines relating to various deprivations of physical liberty provide a basis for comparison in the due process analysis.

Second, an enemy combatant detention deprives the citizen of the opportunity to contest the allegations against him in a criminal proceeding. Criminal prosecution is the usual constitutional procedure for detaining and punishing disloyal behavior. In fact, Justice Scalia, joined by Justice Stevens, argued in Hamdi that criminal prosecution is the only constitutionally 
permissible procedure for dealing with enemy citizens. ${ }^{213}$ By rejecting that conclusion, the remaining Justices authorized the deprivation of the numerous rights that apply in a criminal prosecution, including the right to a grand jury indictment, to a speedy and public trial, to the assistance of counsel, to confront the government's witnesses and evidence, and to proof beyond a reasonable doubt. Although the Due Process Clause requires procedural protections before a citizen may be detained as an enemy combatant, they are not as stringent or protective as the requirements for a criminal prosecution.

Third, because detention as an enemy combatant involves indefinite military custody, the citizen also necessarily is deprived of a number of other constitutional rights. For example, a detainee would not be able to exercise First Amendment free speech rights, whether with the news media or even family and friends. Similarly, a detainee would be denied the ability to participate in the political process, including the right to vote. Although such rights might not be formally taken away by the designation of the citizen as an enemy combatant the way they might be forfeited or restricted upon conviction for a criminal offense, ${ }^{214}$ as a practical matter the citizen would be deprived of them just as thoroughly as criminal procedure rights.

Fourth, one of the government's principal reasons for detaining persons as enemy combatants is to interrogate them for information about terrorist activities. In the case of foreign nationals detained as unlawful enemy combatants under the laws of war, interrogation is a routine practice. ${ }^{215}$ Both Yaser Hamdi and José Padilla were interrogated extensively during their detention as enemy combatants. ${ }^{216}$ Thus, citizens detained as enemy combatants are deprived of their liberty interest against such practices. Enemy combatants are denied an opportunity to invoke the Fifth Amendment

213. See Hamdi v. Rumsfeld, 124 S. Ct. 2633, 2663-64, 2665-70 (2004) (Scalia, J., dissenting). The remaining Justices reaffirmed the existence of the government's power to detain citizens as enemy combatants. See id. at 2639-41 (plurality opinion); id. at 2683-85 (Thomas, J., dissenting); see also id. at 2652-55, 2657-59 (Souter, J., concurring).

214. See, e.g., United States v. Bean, 537 U.S. 71, $74-77$ (2002) (discussing 18 U.S.C. $\S 922$ (2000), felon-in-possession prohibition and restoration of right to possess firearms); Richardson v. Ramirez, 418 U.S. 24, 56 (1974) (holding that state statute denying convicted felons the right to vote did not violate the Equal Protection Clause); see also 18 U.S.C. $\S \S$ 3681-82 (federal "Son of Sam" law prohibiting convicted offenders from profiting from their notoriety).

215. See Allen \& Schmidt, supra note 195, at A1.

216. See Handi v. Rumsfeld, 124 S. Ct. 2633, 2635-37, $2641-42$ (2004) (plurality opinion); Rumsfeld v. Padilla, 124 S. Ct. 2711, 2735 (2004) (Stevens, J., dissenting). 
privilege against self-incrimination or its subsidiary protection in the Miranda rights and warnings. They also may be subjected to various coercive tactics that would not be tolerated in civilian law enforcement under Chavez v. Martinez. ${ }^{217}$ In Padilla, the four dissenting Justices specifically objected that "[e]xecutive detentions ... may not, however, be justified by the naked interest in using unlawful procedures to extract information. Incommunicado detention for months on end is such a procedure."218 Just as other rights give way to military authority in an enemy combatant detention, so too might the Due Process Clause right against coercive interrogation be limited. Even if an outer limit on barbaric torture practices might remain, it is clear that a citizen detained as an enemy combatant has far less rights against government interrogation than a person questioned by civilian law enforcement. This is yet another liberty interest of which the citizen is deprived.

Thus, the deprivations of physical and legal liberty imposed on a citizen by an enemy combatant detention are substantial. Accordingly, the Due Process Clause requires that the government provide significant procedural protections before imposing that status.

\section{Burden of Proof}

The first important question is what burden of proof the Due Process Clause requires the government to satisfy before a court will deny the petition and sustain the government's authority to detain the petitioner as an enemy combatant. The constitutional standards applicable to detentions under civilian law demonstrate that due process principles require that the level of the burden correspond to the extent of the deprivation of liberty. In assessing what burden is necessary for justifying a military detention, therefore, a similar inquiry is required.

\section{a. Seized in the United States}

One of the reasons the Padilla case has been so controversial is that it involves a United States citizen arrested in Chicago, yet denied his constitutional rights. Padilla later was taken into military custody without any judicial oversight of the sufficiency of the grounds for his indefinite detention as an enemy combatant. He has not been charged with any crimes,

217. See supra notes $31-34$ and accompanying text.

218. $124 \mathrm{~S}$. Ct. at 2735 (Stevens, J., dissenting). 
nor has he been given a bail hearing. He has been held incommunicado and was denied access to his counsel. And he apparently has been compelled to submit to interrogation at length for intelligence information. ${ }^{219}$

Were Padilla clearly an agent of a nation with which the United States was at war-like petitioner Haupt in Quirin, a German saboteur who landed on U.S. soil during World War II ${ }^{220}$-it seems unlikely his case would have garnered similar attention. But Padilla has contested the allegations against him both before and after his designation as an enemy combatant. ${ }^{22}$ Yet, perhaps Padilla is a member of Al Qaeda and was planning to commit imminent acts of terrorism upon his return to the United States had he not been arrested. If this is true-if the government's allegations are correct-then Padilla is properly detained as an enemy combatant and denied his constitutional rights. The burden of proof the government must meet plays crucial significance in adjudicating whether an enemy combatant detention of a citizen is justified.

A low burden, such as probable cause, is plainly inadequate. A finding of probable cause supports only a minimal deprivation of liberty: the existence of pending charges and a brief detention pursuant to an arrest. Such intrusions, while not trivial, are insignificant compared to extended incarceration. For this reason, the government's assertion in the Padilla litigation that the courts should review designations of individuals as enemy combatants under the highly deferential "some evidence" standard should be flatly rejected. ${ }^{222}$ Although the invocation of war powers is noteworthy, it cannot justify depriving a citizen of physical liberty and a panoply of constitutional rights on such a thin level of proof. The strong presumption of constitutional rights cannot be overcome so easily.

219. See Padilla v. Rumsfeld, 352 F.3d 695, 699-702 (2d Cir. 2003), rev'd, 542 U.S. 426 (2004). The only judicial oversight was the issuance of the material witness warrant on which Padilla was first arrested and the ongoing habeas corpus proceedings challenging his detention as an enemy combatant. See id.; id. at 732-33 (Wesley, J., concurring in part and dissenting in part).

220. See Ex parte Quirin, 317 U.S. 1, 7 (1942).

221. See 352 F.3d at 699-702 (noting that Padilla and counsel, Newman, were contesting material witness warrants prior to the President designating Padilla as enemy combatant); Padilla ex rel. Newman v. Bush, 233 F. Supp. 2d 564, 599-608 (S.D.N.Y. 2002) (discussing petitioner's intention to contest government's allegations), aff' $d$ in part, rev'd in part sub nom. Padilla v. Rumsfeld, 352 F.3d 695 (2d Cir. 2003), rev'd, 542 U.S. 426 (2004).

222. See Padilla, 233 F. Supp. $2 \mathrm{~d}$ at $605-08$ (discussing and acceding to government's assertion); see also Padilla v. Rumsfeld, 243 F. Supp. 2d 42, 53-57 (S.D.N.Y. 2003) (denying motion for reconsideration). 
Extended involuntary detention may be imposed without a criminal conviction, however. Criminal defendants not yet tried (much less convicted) may be preventively detained under the federal bail statute. ${ }^{223}$ This requires, first, a finding of probable cause to sustain the indictment, and second, a finding by clear and convincing evidence after an adversarial hearing with counsel that detention is necessary to ensure the defendant's appearance for trial or the public safety. Preventive detention pending trial may last for lengthy periods of time without violating the Due Process Clause. ${ }^{224}$

In addition, some forms of civil confinement may be indefinite. Upon a finding by clear and convincing evidence that an individual is both dangerous and unable to control that dangerous behavior due to mental illness, the person may be detained until such time as those two factors no longer exist. ${ }^{225} \mathrm{~A}$ defining feature of the indefinite nature of the confinement, however, is the detainee's lack of culpability with respect to dangerousness due to the mental illness causing the inability to control behavior. It is the mental illness, not the dangerousness alone, which justifies the indefinite civil detention. ${ }^{226}$

The detention of an alleged terrorist as an enemy combatant has some aspects in common with indefinite civil detention, but others that are closer to criminal punishment. On the one hand, to the extent the government seeks only to detain an enemy combatant - whether a lawful combatant as prisoner of war under the Geneva Convention or as an unlawful combatant outside the protections of the treaty-the analogy to civil detention is sound. Like preventive detention of some criminal defendants or the civil confinement of sexual predators, the purpose of enemy combatant detentions is incapacitation: preserving the public safety by preventing the enemy from engaging in further hostilities for the duration of the conflict. On the other hand, unlawful enemy combatants may be interrogated about their involvement in and their knowledge of the armed conflict. Persons subject to civil detention, however, may invoke the Fifth Amendment privilege against compulsory self-incrimination while they are in custody and cannot be subject to compelled interrogation. ${ }^{227}$ Unlawful enemy combatants also may

223. See 18 U.S.C. $\$ 3142(e)(2000)$.

224. United States v. El-Hage, 213 F.3d 74, 79-81 (2d Cir. 2000) (holding that pretrial preventive detention exceeding thirty months did not violate the Due Process Clause, despite the unusual length).

225. See supra Part II.A.2.

226. See supra notes 22-24 (citing cases).

227. See supra Part II.A.3. 
be put on trial before military tribunals for their actions that violate the laws of war. This aspect of their status clearly implicates the goals of retribution and general deterrence that reflect a punitive, rather than a civil, purpose. ${ }^{228}$ Accordingly, evaluating the government's allegations under the same standard applicable to civil confinements does not reflect the potentially profound consequences of the designation of a citizen as an unlawful enemy combatant.

Nevertheless, to impose the highest standard, the criminal law requirement of proof beyond a reasonable doubt, would be inconsistent with the nature of the inquiry at issue. It is not the purpose of a petition for a writ of habeas corpus challenging the prisoner's detention as an enemy combatant to require the government to place the prisoner on trial and to convict him of a criminal offense pursuant to the usual constitutional procedures. A $\$ 2241$ habeas proceeding is not a bench trial of a criminal charge-it is judicial review of the constitutionality of summary executive detention. ${ }^{229}$ After all, if the government's allegations are true, the prisoner does not, in fact, possess the right to have his fate litigated under ordinary rights and doctrines of criminal procedure in the first place. Requiring proof of a criminal conviction to establish that the individual is an enemy combatant not subject to the criminal justice system is illogical.

Finally, some account must be taken of the nature of the inquiry in a $\S 2241$ petition challenging the detention as an enemy combatant of a citizen seized on U.S. soil. Although the presumption of the possession of constitutional rights is strong, the analysis assumes that political branches also assert their maximum possible war powers under the Constitution. Unless that assertion is patently frivolous or tyrannical, it would be inappropriate for the federal courts to contradict the conclusions of the political branches about the grave dangers facing the nation. On the other hand, it is equally inappropriate for the courts to abrogate their responsibility to ensure that war powers justifiably invoked on a general level are being applied properly in the cases of specific citizens. The very purpose for the Great Writ was to permit citizens to challenge summary detention pursuant

228. See Kansas v. Crane, 534 U.S. 407, 412 (2002) (citing Kansas v. Hendricks, 521 U.S. 346, 372-73 (1997) (Kennedy, J., concurring)).

229. Likewise, $\$ 2254$ and $\S 2255$ habeas cases are not retrials of the criminal conviction being challenged; rather, they address specific claims of error asserted to have tainted the earlier proceeding. See 28 U.S.C. $\$ \S 2254-2255$ (2000) (limiting nature of claims); supra note 134 (citing cases regarding nature of habeas claims). 
to executive decree, and the courts should not abandon that responsibility in the face of a claim of military exigency.

In light of the competing constitutional interests, the best solution to the question of the burden of proof is to require the government to justify by clear and convincing evidence the detention of a United States citizen as an enemy combatant. ${ }^{230}$ First, this conclusion is consistent with the idea that proof beyond a reasonable doubt is illogical as the threshold standard. Second, it accords with the burden applied to extended and indefinite detention for non-punitive purposes. Third, although designation as an unlawful enemy combatant may lead to trial by military tribunal rather than a civilian court, permitting that punitive aspect of the designation is a sensible accommodation to the invocation of war powers by the political branches. Fourth, as in other cases applying a clear and convincing evidence standard to indefinite detentions, the burden of proof should be accompanied by a number of significant procedural protections for the petitioner, including access to counsel and the right to contest the government's allegations and present alternative evidence. $^{231}$

In practice, this burden of proof means that the government will have to produce substantial compelling evidence to persuade the court that the citizen seized on U.S. soil is an enemy combatant. If the individual was arrested in preparation for an imminent terrorist attack, then the government should be able to demonstrate those facts with relative ease, just as the government justified preventive detention of the organized crime family leaders in Salerno with recordings and testimony. ${ }^{232}$ And because the $\S 2241$ petition is adjudicated by a judge in a writ proceeding, the Federal Rules of

230. In some respects this analysis is similar to the balancing test of Mathews $v$. Eldridge, which the Hamdi plurality opinion applied in analyzing the due process issues. See Hamdi v. Rumsfeld, 124 S. Ct. 2633, 2646-50 (2004) (plurality opinion) (applying Mathews v. Eldridge, 424 U.S. 319 (1976)); see also id. at 2672-73 (Scalia, J., dissenting) (criticizing application of Mathews standard); cf. Jessalyn Radack, You Say Defendant, I Say Combatant: The Opportunistic Treatment of Terrorism Suspects Held in the United States and the Need for Due Process, 29 N.Y.U. REV. L. \& Soc. CHANGE 525, 546-50 (2005) (applying Mathews standard). This analysis considers the requirements of due process primarily in relation to the other constitutional doctrines of detention and deprivations of physical liberty, a form of structural constitutional argument. To the extent the analysis takes account of the government's interest in national security, however, the analysis follows a functional approach similar to Mathews.

231. See infra Part IV.B.3.

232. See supra note 21 and accompanying text. 
Evidence and other strict trial procedures are not directly applicable, ${ }^{233}$ just as they are not in a bail or a suppression motion hearing in a criminal case. Nonetheless, the government's burden is a high one and seeking to carry it principally with hearsay and summaries might fail to persuade the judge that the proof is sufficient. By comparison, if the individual is alleged to be an enemy combatant based on active membership in Al Qaeda, then the government may have to reveal significant portions of the basis for that allegation. A simple conclusory affidavit by a government official is plainly insufficient. ${ }^{234}$ Particularly if the petitioner raises a significant challenge such as mistaken identity or alibi, the government may be required to reveal even more evidence to satisfy its burden of proof. The government might fear that requiring this level of proof may lead to the public disclosure of intelligence information, confidential informants, or other sensitive matters, but this is a price the government must be willing to pay if it seeks to deny a citizen his constitutional rights on the accusation that he is an enemy combatant.

Thus, a comprehensive view of the conflicting interests explains why clear and convincing evidence is the appropriate burden of proof for these $\S 2241$ petitions. On the one hand, this standard permits punitive sanctions by a later military tribunal without the usual criminal procedure protections and the interrogation of the individual without the protections of the Fifth Amendment privilege. On the other hand, it requires the government to surpass a rigorous review even at the fullest extent of its domestic constitutional war powers. Although the detention of a citizen as an enemy combatant has greater consequences than preventive detention of an accused criminal without bail or indefinite civil confinement of the mentally ill, $^{235}$ proof by the same standard used in those situations prevents arbitrary or unsupportable detentions, while also providing the government the power to protect the public from those it can persuasively demonstrate are terrorists.

233. See 28 U.S.C. $\$ \$ 2241$ (a), 2243.

234. Compare Padilla ex rel. Newman v. Bush, 233 F. Supp. 2d 564, 572-73, 605-10 (S.D.N.Y. 2002) (discussing Mobbs Declaration regarding Padilla), aff'd in part, rev'd in part sub nom. Padilla v. Rumsfeld, 352 F.3d 695 (2d Cir. 2003), rev'd, 542 U.S. 426 (2004), with Hamdi v. Rumsfeld, 316 F.3d 450, 461, 469-77 (4th Cir. 2003) (discussing Mobbs Declaration regarding Hamdi), rev'g, 243 F. Supp. 2d 527 (E.D. Va. 2002), vacated, 542 U.S. 507 (2004).

235. See supra Parts II.A.2-3, IV.B.1. 


\section{b. Seized Abroad}

The analysis of the seizure of United States citizens abroad is considerably more complex. In some situations the seizure will be virtually indistinguishable from a similar seizure in the United States-for example, an expatriate citizen living in Paris, London, or Berlin and arrested on suspicion of active membership in Al Qaeda, rather than in preparation for an imminent terrorist attack, is little different than a citizen arrested in New York, Los Angeles, or Boston. In other situations, the seizure will be a classic battlefield detention of an enemy soldier in a foreign zone of combat where constitutional war powers are at their maximum - such as a citizen fighting with the Taliban. To what extent should the government's burden of proof be altered to account for these differing situations?

The best solution to this question is to retain the same standard applied to seizures within the United States, proof by clear and convincing evidence, and leave it to the judgment of the courts to adjudicate whether the government's allegations outweigh the petitioner's challenges in the totality of the circumstances. The nature of the factual dispute in each particular case, therefore, will determine the ease with which the government can meet this burden.

On the one hand, if the petition claims the prisoner was seized in civilian circumstances in a place that is not an active zone of combat, the government either must prove that the petition is factually inaccurate because the prisoner was in fact seized on a battlefield or must provide similar proof to a detention in the United States, such as that the prisoner is an active member of Al Qaeda. That is, citizens should not be given lesser protection against designation as enemy combatants simply because they reside abroad or travel as tourists to foreign countries.

On the other hand, if the petition cannot reasonably contest that the prisoner was seized in a place where the United States is engaged in active military operations, the government would be able to carry its burden with less difficulty. It would not be appropriate, for example, to require the government to provide the direct testimony of the individual U.S. soldiers involved in the specific seizure of the prisoner on a battlefield; rather, an affidavit from a commanding officer describing and summarizing the conditions of the capture might be sufficient. Likewise, the concessions of the petition itself might doom the claim in light of the government's 
allegations. ${ }^{236}$ Yet, there also might be contested claims, such as an individual the government claims was captured fighting for an enemy militia, but whose petition maintains was a journalist or non-belligerent humanitarian relief worker. ${ }^{237}$ In such disputes, the government must provide sufficient proof to persuade the court that it has clearly and convincingly refuted the petition's contentions and is properly detaining the person as an enemy combatant.

Thus, in cases where the government can readily demonstrate that the place where the prisoner was seized was an active zone of foreign combat, it will be correspondingly easier to justify the enemy combatant status of the person. In other cases, where those circumstances are far more ambiguous, the government must justify the enemy combatant detention with a level of proof comparable to a seizure within the United States.

\section{c. Concessions and "Undisputed" Facts}

In some cases, the government may seek to carry its burden of proof by arguing that certain facts are undisputed or have been conceded by the petitioner and that those facts necessarily doom the petition's prayer for relief. While this argument sometimes has force, due process requires that the government not be permitted to evade its burden of proof through inferences and conclusions that range beyond the scope of the actual nature of any conceded or undisputed facts.

For example, in the Hamdi litigation, the petition admitted that Hamdi "resided in Afghanistan" at the time he was "seized by the United States Government."238 From this admission and the bare allegations of the government's conclusory affidavit, the Fourth Circuit held that Hamdi conceded facts that authorized his detention as an enemy combatant. ${ }^{239}$ Dissenting from the denial of rehearing en banc, several judges rejected this conclusion because the fact that Hamdi was present in Afghanistan when he was taken into custody did not permit the inference that he had in fact taken

236. See infra Part IV.B.2.c.

237. See Hamdi v. Rumsfeld, 337 F.3d 335, 357-58 (4th Cir. 2003) (Luttig, J., dissenting) (arguing that fact of seizure in Afghanistan was not conclusive of enemy combatant status), vacated, 542 U.S. 507 (2004); id. at 371-74 (Motz, J., dissenting) (same).

238. Hamdi v. Rumsfeld, 124 S. Ct. 2633, 2645 (2004) (plurality opinion) (quoting petition).

239. Hamdi, 316 F.3d at 473-76. 
up arms against the United States as an enemy combatant. ${ }^{240}$ The plurality opinion in the Supreme Court agreed with this analysis: "We reject any argument that Hamdi has made concessions that eliminate any right to further process."241 The Court explained that the undisputed or conceded facts must be compared to the legal standard at issue: the definition of an enemy combatant. ${ }^{242}$ The facts that Hamdi was residing in Afghanistan and was seized there by United States military forces were not at all the same as concessions that he was engaged in armed conflict against the United States. ${ }^{243}$ Accordingly, the petition did not concede any facts that doomed its claims.

The plurality opinion in Hamdi applied the correct analysis to the government's argument that undisputed or conceded facts defeated the petition. A citizen is an enemy combatant only in certain narrow circumstances; ${ }^{244}$ otherwise the citizen must be given the full scope of constitutional rights and cannot be detained in military custody. Moreover, the Due Process Clause mandates that the government prove by clear and convincing evidence that the citizen meets that narrow definition. ${ }^{245}$ Thus, the only facts that can satisfy that burden are those that establish that the citizen is in fact an enemy belligerent engaged in imminent armed conflict against the United States-facts demonstrating the actions and intent of a soldier committing war crimes, not an ordinary criminal violating the civilian laws. ${ }^{246}$ When the government seeks to carry its burden directly, with proffered evidence and witnesses, it must prove facts that specifically meet that definition. The government's proof must be held to the same standard when it seeks to carry its burden through reliance on undisputed facts or concessions by the petitioner. Only if the facts at issue, proven or conceded, actually meet the applicable definition of an enemy combatant has the government met its burden under the Due Process Clause.

240. See Hamdi, 337 F.3d at 351 (Traxler, J., concurring); id. at 357-65 (Luttig, J., dissenting); id. at 370-73 (Motz, J., dissenting).

241. Hamdi, 124 S. Ct. at 2645 (plurality opinion).

242. See id.

243. See id.

244. See text accompanying supra note 180 .

245. See text accompanying supra note 181.

246. For example, in Quirin, the Court held that the petitions conceded facts that constituted belligerency in violation of the laws of war. See Ex parte Quirin, 317 U.S. 1, 2024, 45-46 (1942). 


\section{Access to Counsel and Related Procedural Protections}

The second critical inquiry under the Due Process Clause is the nature and scope of the procedural protections that complement the burden of proof. For that burden to have any real significance, the government's proof must be made through a range of procedural rights and obligations that enable the petitioner to meaningfully contest the government's allegations of enemy combatant status. Again, because the presumption of constitutional rights is a strong one and the military detention of a citizen as an enemy combatant is an extraordinary power, due process requires that these procedural protections be substantial. Likewise, because the scope of the deprivation of liberty in an enemy combatant detention is extensive, the Due Process Clause requires stringent procedural protections comparable to those mandated for similarly serious deprivations of liberty before an enemy combatant detention is constitutional. ${ }^{247}$ Without such rigorous procedures, due process principles would be violated.

The Supreme Court in Hamdi gave only brief mention of the due process requirements for judicial review of an enemy combatant detention. A majority of the Court agreed that the Due Process Clause requires, at a minimum, notice of the government's factual allegations and a fair and meaningful opportunity to contest and to rebut those allegations before a neutral decision-maker. ${ }^{248}$ Seven Justices also agreed that the petitioner would have a right of access to counsel in pursuing the challenge to detention. ${ }^{249}$ Additionally, the plurality opinion suggested that these minimum procedures might be accompanied by certain limitations on the procedural protections to account for the government's national security interests, such as the acceptance of hearsay evidence, possible use of a burden-shifting framework once the government proffers its evidence, or a military tribunal as the decision-maker. ${ }^{250}$ Neither the majority-approved requirements nor the plurality's suggestions were elaborated in any detail, however, and the due process issues were remanded to the lower courts for

247. See supra note 181 .

248. See Hamdi v. Rumsfeld, 124 S. Ct. 2633, $2648-49$ (2004) (plurality opinion); id. at 2660 (Souter, J., concurring); see also Rumsfeld v. Padilla, 124 S. Ct. 2711, 2735 \& n.9 (2004) (Stevens, J., dissenting).

249. See. Hamdi, 124 S. Ct. at 2652 (plurality opinion); id. at 2660 (Souter, J., concurring); see also Rumsfeld, 124 S. Ct. at 2735 (Stevens, J., dissenting).

250. See Hamdi, $124 \mathrm{~S}$. Ct. at 2649, 2651 (plurality opinion). The concurring Justices did not join the plurality on these points. See id. at 2660 (Souter, J., concurring). 
further development of the law as well as the facts. ${ }^{251}$ Accordingly, after Hamdi, the scope and the nature of due process mandates for challenges to enemy combatant detentions remains unresolved.

The minimum basic requirements established by the Hamdi Court are sound, but the Court did not go far enough in providing procedural protections to citizens challenging their military detention as enemy combatants. A citizen so detained is subject not only to indefinite detention for the duration of the armed conflict, but also is deprived of the constitutional rights he or she otherwise would possess, including the right against compelled interrogation. ${ }^{252}$ These consequences for the citizen are severe and result in a greater loss of physical and constitutional liberties than either imprisonment for a criminal conviction or indefinite non-punitive civil detention. Accordingly, the Due Process Clause mandates that the government surpass significant procedural hurdles before imposing those consequences.

First, due process requires that the prisoner be given notice of the factual allegations underlying the President's designation of the citizen as an enemy combatant. This basic requirement applies in a wide range of proceedings to which the Due Process Clause applies, such as administrative hearings. ${ }^{253}$ It also is analogous to the Indictment and Notice Clauses applicable to criminal cases ${ }^{254}$ rights that the petitioner loses if enemy combatant status is found. In the context of an enemy combatant detention, the requirement provides the prisoner with the ability to contest the government's allegations in whatever ways are possible, from simpler defenses like mistaken identity or alibi to more complex claims that directly confront the government's assertions about the petitioner's activities, allegiances, and intentions. For the notice to be effective, the government must produce and delineate the specific factual allegations that bring the petitioner within the category of persons qualifying as enemy combatants. ${ }^{255}$ While a cursory, summary notice might be

251. See id. at 2660 (Souter, J., concurring) (noting lack of clear direction in remand instructions).

252. See supra Part IV.B.1.

253. See id. (citing cases); see also, e.g., Dusenbery v. United States, 534 U.S. 161, 167-68 (2002); W. Covina v. Perkins, 525 U.S. 234, 240-41 (1999); Mullane v. Cent. Hanover Bank \& Trust Co., 339 U.S. 306, 313-14 (1950). See generally 3 RoNALD D. ROTUNDA \& John E. Nowak, Constitutional Law: Substance \& Procedure $\$ 17.8$ (3d ed. 1999 \& Supp. 2003) (discussing fundamental due process principles).

254. See U.S. CONST. amends. V-VI; 5 LAFAVE ET AL., supra note 7, § 19.2.

255. See supra Part IV.A. 
acceptable for administrative hearings with limited stakes, ${ }^{256}$ the deprivations of liberty imposed by an enemy combatant detention are severe, and accordingly, due process mandates a high degree of specificity of the notice, comparable to that in a criminal charging document or a civil commitment proceeding. Without such specific and particularized notice tailored to the allegation of enemy combatant status, the petitioner cannot fairly understand and respond to the detention designation.

Second, the petitioner must be given a fair and meaningful opportunity to contest the government's allegations in an adversarial hearing before a neutral decision-maker. This requirement also is a core mandate of the Due Process Clause imposed in a wide variety of contexts; ${ }^{257}$ for that reason the requirement is limited in scope. Yet, even that limited scope demonstrates that the hearing adjudicating the legality of the citizen's detention as an enemy combatant must be an adversarial hearing. In the civilian criminal justice system, ex parte hearings are permitted only for minor infringements on liberty, such as judicial review of probable cause to arrest and grand jury determinations of probable cause to indict. Similarly, even in the civil and administrative contexts, adversarial hearings are required for deprivations of liberty or property far less significant than the substantial loss of constitutional rights at stake in an enemy combatant detention. ${ }^{258}$ Nevertheless, hearings with far fewer procedural protections than a criminal case or those set forth here still meet the meaningful opportunity requirement. ${ }^{259}$ For that reason, most of the weight of the requirement stems from the necessity of an impartial decision-maker, which prevents the government from providing an apparent process that actually has a foregone conclusion. ${ }^{260}$ Hence, this component of the due process analysis, while important, has less significance than the other procedural requirements.

256. For example, the degree of factual specificity in a citation for a traffic infraction is considerably less than in a criminal felony indictment.

257. See Hamdi, $124 \mathrm{~S}$. Ct. at $2648-49$ (plurality opinion) (citing cases); Bracy v. Gramley, 520 U.S. 899, 904-09 (1997); Gibson v. Berryhill, 411 U.S. 564, 579 (1973); Ward v. Monroeville, 409 U.S. 57, 59-60 (1972); Tumey v. Ohio, 273 U.S. 510,523 (1927).

258. See, e.g., Friedman v. Rogers, 440 U.S. 1, 18 (1979) (professional disciplinary proceeding). See generally 3 RoTUNDA \& NowAK, supra note 253, $\S 17.8$.

259. See Cleveland Bd. of Educ. v. Loundermill, 470 U.S. 532, 544 (1985) (discharge from government employment); Bell v. Burson, 402 U.S. 535, 541-42 (1971) (suspension of driver's license); Goldberg v. Kelly, 397 U.S. 254, 267-68 (1970) (loss of government welfare benefits).

260. See supra note $257 ; 3$ RoTUNDA \& NowAK, supra note $253, \S 17.8$. 
When a citizen uses a $\S 2241$ petition to challenge his or her detention as an enemy combatant, a hearing before the Article III judge assigned to the case provides an appropriate occasion for the fair and meaningful opportunity to contest the government's allegations before a neutral decisionmaker. As in Hamdi and Padilla, rather than convening ad hoc or administrative hearings within the Executive Branch that must then be reviewed by a court in a habeas proceeding, the more expeditious and effective procedure is to adjudicate the legality of the citizen's detention in the $\S 2241$ proceeding in the first instance. ${ }^{261}$ That hearing would ensure both judicial review and compliance with the requirements of the Due Process Clause. ${ }^{262}$

Third, the adversarial hearing must be conducted with the right to counsel to assist the petitioner in pursuing the challenge to the detention. The Supreme Court mandated a constitutional right to counsel under the Sixth Amendment in all criminal cases in which imprisonment for any length of time, no matter how brief, is imposed. ${ }^{263}$ The Due Process Clause also requires a right to counsel when incarceration is imposed as a penalty for a civil contempt of court, ${ }^{264}$ and the procedures approved by the Court for preventive detention and civil commitment included a right to counsel at the

261. Whether use of a military tribunal to adjudicate the sufficiency of the government's proof to justify an enemy combatant detention satisfies due process, particularly the full and fair adversarial hearing and the impartial decision-maker requirements, is an open question. That issue is a considerable topic of debate in the literature on military tribunals. See supra note 83 for sources on this topic.

262. In Hamdi, Justice Scalia maintained that the Due Process Clause is the right protected against infringement and that habeas corpus proceedings are the means used to secure that right. See $124 \mathrm{~S}$. Ct. at 2661-63, 2672-73 (Scalia, J., dissenting). Accordingly, he argued, "The role of habeas corpus is to determine the legality of executive detention, not to supply the omitted process necessary to make it legal." Id. at 2672. If the Executive Branch is willing to accede to prompt judicial review of enemy combatant detentions through $\S 2241$ proceedings in Article III courts, however, then both the government's and the petitioner's interests are vindicated. For this reason, the Due Process Clause should not be interpreted to require a hearing prior to the adjudication of the $\S 2241$ petition under the procedures set forth in the text, as Justice Scalia's view would seem to insist.

263. See, e.g., Alabama v. Shelton, 535 U.S. 654, 662 (2002) (right to counsel in misdemeanor cases in which any actual imprisonment is imposed); Gideon v. Wainwright, 372 U.S. 335, 342 (1963) (right to counsel in all felony cases).

264. See, e.g., Wilson v. New Hampshire, 18 F.3d 40, 41 (1st Cir. 1994); Schoenberg v. Shapolsky Publishers, Inc., 971 F.2d 926, 934-35 (2d Cir. 1992). A criminal contempt of court is a criminal case to which the Sixth Amendment right to counsel attaches. See FED. R. CRIM. P. 42(b). 
hearing where the determination to detain was made. ${ }^{265}$ Finally, the Court ruled that due process requires a right to counsel in certain limited types of civil cases in which the government seeks to deprive a person of a fundamental right, even when no physical confinement is possible. ${ }^{266}$ Because the consequences of a determination that a citizen is an enemy combatant involves both physical confinement and deprivation of constitutional rights, the Due Process Clause requires the right to counsel in the proceeding adjudicating the legality of that designation.

Fourth, the petitioner must be given the fullest possible opportunity to contest the government's case and to present a case in rebuttal. The government's evidence that the prisoner is an enemy combatant must be made open to challenge and cross-examination. To the extent classified information is material and relevant to the petitioner's defense against the allegations, due process should require the government either to permit the petitioner to make use of the information or to abandon the attempt to impose an enemy combatant detention, similar to the principles applied in criminal cases. ${ }^{267}$ Although the full scope of the criminal Confrontation Clause right is not applicable, ${ }^{268}$ the use of hearsay evidence alone almost certainly would be inadequate to prove enemy combatant status by clear and convincing

265. See supra notes 19-20, 23 and accompanying text.

266. See, e.g., Lassiter v. Dep't of Soc. Servs., 452 U.S. 18, 31-32 (1981) (right to counsel in some parental rights termination proceedings).

267. For example, the government's refusal to make certain potentially exculpatory witness available to the defense in the Moussaoui prosecution violated the defendant's constitutional right to compulsory process. See United States v. Moussaoui, 365 F.3d 292, 307 (4th Cir. 2004), vacated, 382 F.3d 453 (4th Cir. 2004), cert. denied, 125 S. Ct. 1670 (2005). A criminal defendant also has a Due Process Clause right of access to all material, exculpatory information and evidence in the government's possession. See, e.g., Kyles v. Whitley, 514 U.S. 419, 432-33 (1995); United States v. Bagley, 473 U.S. 667, 674 (1985); Brady v. Maryland, 373 U.S. 83, 87 (1963); 5 LAFAVE ET AL., supra note 7, §24.3(a)-(b). The Classified Information Procedures Act (the "CIPA") similarly provides that when classified information is material to a criminal defendant's case, the government must either provide the information (or an adequate substitute approved by the court) or dismiss the prosecution. See 18 U.S.C. App. 3, $\S \S 1-16$ (2000 \& Supp. 2003); see also, e.g., United States v. Moussaoui, 333 F.3d 509, 514-15 (4th Cir. 2003) (discussing applicability of CIPA), vacated, 382 F.3d 453 (4th Cir. 2004), cert. denied, 125 S. Ct. 1670 (2005); United States v. Rezaq, 134 F.3d $1121,1142-43$ (D.C. Cir. 1998) (applying CIPA).

268. See Crawford v. Washington, 541 U.S. 36, 68-69 (2004) (imposing Confrontation Clause limitations on use of testimonial hearsay at criminal trials); $i d$. at 43-50 (discussing Confrontation Clause precedent). 
evidence. ${ }^{269}$ Similarly, the Hamdi plurality's suggestion of a burden-shifting framework is inconsistent with the nature of the due process inquiry for enemy combatant detentions: given the extraordinary power at issue, the government must shoulder the obligation of justifying its action with persuasive proof. Only if the government's evidence is subjected to the scrutiny of vigorous adversarial testing is it appropriate to allow a citizen to be detained as an enemy combatant and deprived of constitutional rights.

Thus, the Due Process Clause requires significant and substantial procedural protections for the determination whether a citizen is an enemy combatant. As with the burden of proof, these procedures are less than the full constitutional protections applicable to trial of a criminal case, but they nevertheless are considerable - procedures equivalent to the hearings used to impose preventive detention or civil commitment. In light of the consequences for the petitioner of enemy combatant status, these rigorous procedural requirements are necessary to provide due process of law.

\section{CONCLUSION}

The power to detain citizens as enemy combatants is an extraordinary one. Alleged terrorists held in military custody are deprived of physical liberty and a range of constitutional rights they otherwise would possess. Accordingly, the Due Process Clause requires that the government surpass substantial procedural hurdles before imposing the significant deprivations of liberty that accompany an enemy combatant detention.

Citizens held in military custody may file a $\S 2241$ habeas petition challenging their detentions as an enemy combatant by order of the President. In hearing these petitions, the federal courts provide judicial review of enemy combatant detentions and vindicate the ancient purpose of the Great Writ. To detain a citizen as an enemy combatant, the government must prove that the individual is a belligerent under the laws of war and not merely an ordinary criminal-even a traitor-entitled to the full constitutional protections of civilian law.

Due process principles command that a citizen be detained as an enemy combatant only if he or she is personally engaged in armed conflict against the United States under the laws of war. When considering alleged terrorists,

269. See supra notes 19-21 and accompanying text (discussing evidence used to justify preventive detention without bail by clear and convincing evidence in United States $v$. Salerno, 481 U.S. 739 (1987)). 
as opposed to soldiers seized on a battlefield in a theater of conventional war, belligerency under the laws of war requires proof that the individual is an active present member of a terrorist organization that is engaged in armed conflict with the United States and that the individual has the specific intent to carry out imminent acts of terrorism against the United States. Together these two requirements ensure that the citizen is part of an armed force governed by the laws of war and that the citizen is actually engaged in violations of the laws of war. Absent these factors, the citizen cannot be removed from civilian jurisdiction or deprived of physical liberty without the full scope of constitutional rights.

The Due Process Clause imposes significant procedural requirements on the government's proof of enemy combatant status in the habeas proceeding. The government must prove that the alleged terrorist qualifies as an enemy combatant by clear and convincing evidence, the burden of proof that best reflects the extent of the deprivations of liberty at stake and the threshold nature of the determination in the habeas case. The government must provide specific factual notice of its allegations of belligerency under the laws of war and must allow the petitioner a full opportunity to face the allegations in an adversarial manner. Given the deprivation of physical and constitutional liberty imposed by an enemy combatant detention, due process mandates that the petitioner be given access to counsel in contesting the government's claims. Similarly, the petitioner must be allowed to deny the government's proof by challenging the evidence introduced in support of belligerency and by presenting evidence in rebuttal. Only if the government can carry its high burden through these rigorous procedures does the Due Process Clause permit a citizen to be detained as an enemy combatant. 